\title{
Corrective Measures Study Modeling Results for the Southwest Plume - Burial Ground Complex/Mixed Waste Management Facility
}

by

M. K. Harris

Westinghouse Savannah River Company

Savannah River Site

Aiken, South Carolina 29808

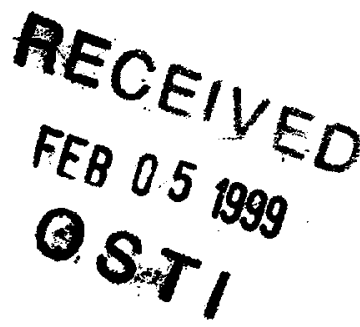

G. P. Flach

This paper was prepared in connection with work done under the above contract number with the U. S. Department of Energy. By acceptance of this paper, the publisher and/or recipient acknowledges the U.S. Government's right to retain a nonexclusive, royalty-free license in and to any copyright covering this paper, along with the right to reproduce and to authorize others to reproduce all or part of the copyrighted paper. 
WSRC-TR-96-0411

Corrective Measures Study Modeling Results for the Southwest Plume - Burial Ground Complex/Mixed Waste Management Facility (U)

G.P Flach, M.K. Harris

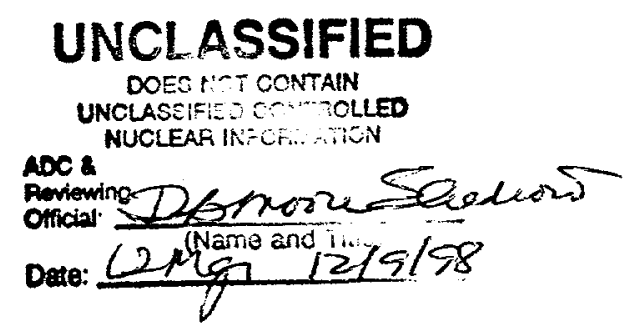

Westinghouse Savannah River Company

Savannah River Site

Aiken, S.C. 29808

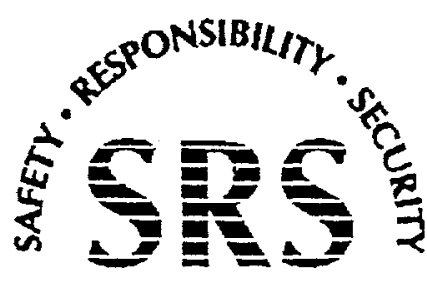




\section{DISCLAIMER}

This report was prepared as an account of work sponsored by an agency of the United States Government. Neither the United States Government nor any agency thereof, nor any of their employees, makes any warranty, express or implied, or assumes any legal liability or responsibility for the accuracy, completeness, or usefulness of any information, apparatus, product, or process disclosed, or represents that its use would not infringe privately owned rights. Reference herein to any specific commercial product, process, or service by trade name, trademark, manufacturer, or otherwise does not necessarily constitute or imply its endorsement, recommendation, or favoring by the United States Government or any agency thereof. The views and opinions of authors expressed herein do not necessarily state or reflect those of the United States Government or any agency thereof.

This report has been reproduced directly from the best available copy.

Available to DOE and DOE contractors from the Office of Scientific and Technical Information, P.O. Box 62, Oak Ridge, TN 37831; prices available from (615) 576-8401.

Available to the public from the National Technical Information Service, U.S. Department of Commerce, 5285 Port Royal Road, Springfield, VA 22161.

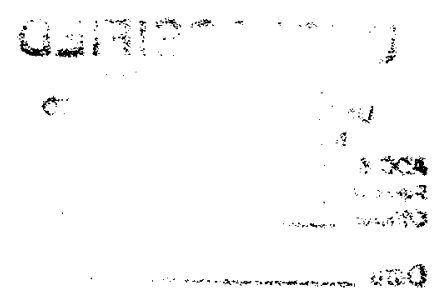




\section{DISCLAIMER}

Portions of this document may be illegible in electronic image products. Images are produced from the best available original document. 
WSRC-TR-96-0411

Corrective Measures Study Modeling Results for the Southwest Plume - Burial Ground Complex/Mixed Waste Management Facility (U)

G.P Flach, M.K. Harris

Publication Date: January 1997

Westinghouse Savannah River Company Savannah River Site Aiken, S.C. 29808

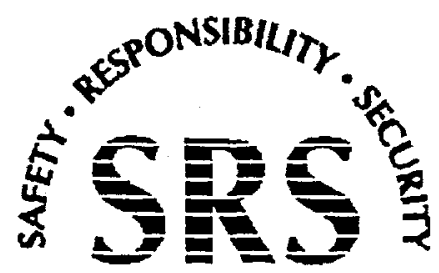


Corrective Measures Study Modeling Results for the Southwest Plume - Burial Ground Complex/Mixed Waste Management Facility (U)

Authentication and Approvals:

\begin{tabular}{ll}
\hline G.P Flach, Author Date & Dar
\end{tabular}




\section{Executive Summary}

Groundwater modeling scenarios were performed to support the Corrective Measures Study and Interim Action Plan for the southwest plume of the Burial Ground Complex/Mixed Waste Management Facility. The modeling scenarios were designed to provide data for an economic analysis of alternatives, and subsequently evaluate the effectiveness of the selected remedial technologies for tritium reduction to Fourmile Branch. Modeling scenarios assessed include no action, vertical barriers, pump, treat, and reinject; and vertical recirculation wells.

Three-dimensional plume maps were produced for the tritium and TCE plumes emanating from the southwest corner of the Burial Ground Complex/Mixed Waste Management Facility. Tritium plume maps were created for the $>20,000 \mathrm{pCi} / \mathrm{ml},>500 \mathrm{pCi} / \mathrm{ml}$ and $>50 \mathrm{pCi} / \mathrm{ml}$ concentration levels. TCE plume maps were created for the $>200 \mathrm{ppb}>40 \mathrm{ppb}$, and the $>10 \mathrm{ppb}$ concentrations levels. Volumetric calculations were performed for both the tritium and TCE maps. The 3D tritium plume maps and volumetrics show that about $63 \%$ of the total activity resides in a $<20^{\prime}$ thick layer above the "tan clay" confining zone comprising about $12 \%$ of the $>50 \mathrm{pCi} / \mathrm{ml}$ plume by volume.

Computer simulation and analysis were performed on the selected remedial technologies for preliminary design input. Key design parameters were compiled for input to an economic analysis of alternatives. Example parameters include the number, location, and pumping rates of extraction wells. Each design was simulated using the Flow And Contaminant Transport (FACT) groundwater flow and contaminant transport code. The reduction in tritium discharge to Fourmile Branch that would result from each evaluated technology was estimated. 


\section{Contents}

Executive Summary $\ldots \ldots \ldots \ldots \ldots \ldots \ldots \ldots \ldots \ldots \ldots \ldots \ldots \ldots \ldots \ldots \ldots \ldots$ iii

List of Tables $\ldots \ldots \ldots \ldots \ldots \ldots \ldots \ldots \ldots \ldots \ldots \ldots \ldots \ldots \ldots \ldots \ldots \ldots \ldots$

List of Figures $\ldots \ldots \ldots \ldots \ldots \ldots \ldots \ldots \ldots \ldots \ldots \ldots \ldots \ldots \ldots \ldots \ldots \ldots \ldots$

Objective ......................................

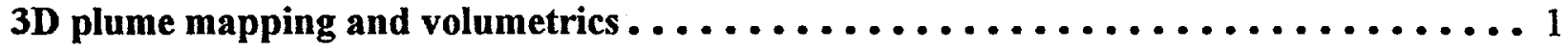

Methodology .................................

Results................................. 1

Benefits .................................. 1

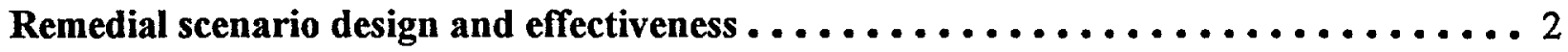

Methodology .................................

No action .................................... 2

Vertical barriers ................................... 2

Pump, treat (VOC) and reinject ......................... 3

Upper and Lower Water Table capture $\ldots \ldots \ldots \ldots \ldots \ldots \ldots \ldots \ldots \ldots \ldots \ldots$

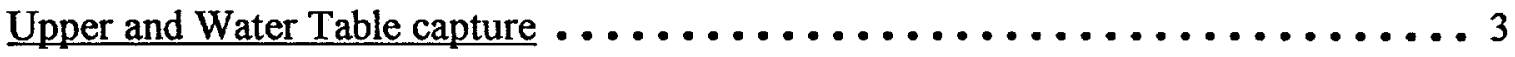

"Hot layer" capture .................................. 4

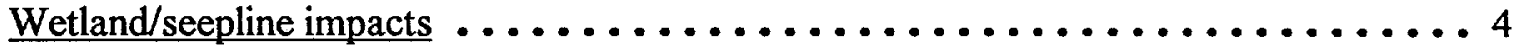

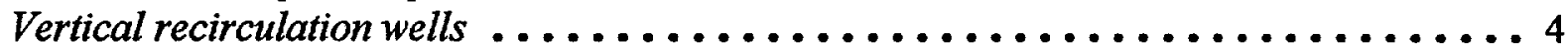

References ....................................... 5

Appendix A ................................... 41

Appendix B..................................... 49 


\section{List of Tables}

Table 1 Volumetric results of $3 \mathrm{D}$ plume mapping study $\ldots \ldots \ldots \ldots \ldots \ldots \ldots \ldots$

Table 2 Locations of extraction and reinjection wells for "hot layer" tritium capture . . . . 7 


\section{List of Figures}

Figure 1 Predicted Groundwater Flowlines from the FACT numerical model . . . . . . . 8

Figure 2 Cross-section grid - tritium plume $\ldots \ldots \ldots \ldots \ldots \ldots \ldots \ldots \ldots \ldots \ldots$

Figure 3 Cross-section grid - TCE plume ....................... 10

Figure 4 Plan view of tritium $A C L$ plume $>20,000 \mathrm{pCi} / \mathrm{ml} \ldots \ldots \ldots \ldots \ldots \ldots \ldots \ldots$

Figure 5 Side view (looking west) of tritium ACL plume $>20,000 \mathrm{pCi} / \mathrm{ml} \ldots \ldots \ldots \ldots$

Figure 6 Cross-sectional view (looking east) of tritium ACL plume $>20,000 \mathrm{pCi} / \mathrm{ml}$ with water table surface ............................ 13

Figure 7 Plan view of tritium plume $>500 \mathrm{pCi} / \mathrm{ml} \ldots \ldots \ldots \ldots \ldots \ldots \ldots \ldots \ldots \ldots \ldots$

Figure 8 Plan view of tritium plume $>50 \mathrm{pCi} / \mathrm{ml} \ldots \ldots \ldots \ldots \ldots \ldots \ldots \ldots \ldots$

Figure 9 Plan view of TCE plume $>200 \mathrm{ppb}$ and PCE plume $>100 \mathrm{ppb} \ldots \ldots \ldots$

Figure 10 Plan view of TCE plume $>40 \mathrm{ppb} \ldots \ldots \ldots \ldots \ldots \ldots \ldots \ldots \ldots \ldots \ldots \ldots$

Figure 11 Side view (looking west) of TCE plume $>40 \mathrm{ppb} \ldots \ldots \ldots \ldots \ldots \ldots \ldots \ldots$

Figure 12 Cross-sectional view (looking east) of TCE Plume $>40 \mathrm{ppb}$ with water table

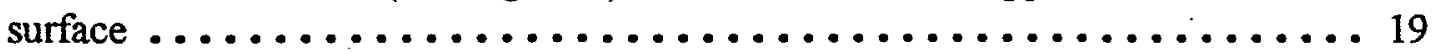

Figure 13 Plan view of TCE Plume $>10 \mathrm{ppb} \ldots \ldots \ldots \ldots \ldots \ldots \ldots \ldots \ldots \ldots \ldots \ldots \ldots . \ldots \ldots$

Figure 14 Tritium discharge for no action scenario $\ldots \ldots \ldots \ldots \ldots \ldots \ldots \ldots \ldots$

Figure 15 Vertical barrier configuration. . . . . . . . . . . . . . . . . . . 22

Figure 16 Tritium discharge for vertical barrier scenarios . . . . . . . . . . . . . . 23

Figure 17 Location of wells for extraction and reinjection scenarios . . . . . . . . . . . . 24

Figure 18 Capture zone within the "Upper Water Table" for well screens above and below the "Tan Clay Confining Zone" (200' elevation) . . . . . . . . . . . . . . . 25

Figure 19 Capture zone within the "Lower Water Table" for well screens above and below the "Tan Clay Confining Zone" (180' elevation) . . . . . . . . . . . . . . . . . 26

Figure 20 Tritium discharge for "Upper and Lower Water Table" capture . . . . . . . . . . 27

Figure 21 Capture zone within the "Upper Water Table" for well screens above and below the "Tan Clay Confining Zone" with reinjection (200' elevation) . . . . . . . . . . 28

Figure 22 Capture zone within the "Lower Water Table" for well screens above and below the "Tan Clay Confining Zone" with reinjection (180' elevation) . . . . . . . . . . . 29

Figure 23 Fate of reinjected tritiated groundwater, $210^{\prime}$ elevation . . . . . . . . . . . 30

Figure 24 Fate of reinjected tritiated groundwater, $190^{\prime}$ elevation . . . . . . . . . . . . . 31

Figure 25 Capture zone within the "Upper Water Table" for well screens above the "Tan Clay Confining Zone" (200' elevation) . . . . . . . . . . . . . . . . 32

Figure 26 Tritium discharge for "Upper Water Table" capture . . . . . . . . . . . . . . 33

Figure 27 Capture zone within the "Upper Water Table" for well screens above the "Tan Clay Confining Zone" with reinjection (200' elevation) . . . . . . . . . . . 34

Figure 28 Fate of reinjected tritiated groundwater $\left(210^{\prime}\right.$ elevation) $\ldots \ldots \ldots \ldots \ldots$

Figure 29 Vertical capture height for depth discrete extraction of "hot layer" scenario . . . 36

Figure 30 Extraction well placement for "hot layer" extraction scenario . . . . . . . . . 37

Figure 31 Capture zone for vertical recirculation wells - VOC "hot spots" . . . . . . . . . 38

Figure 32 Groundwater flow from vertical recirculation well injection screens - VOC "hot spots" . . . . . . . . . . . . . . . . . . . . . . . . . . . . . . 39 


\section{Objective}

Provide modeling support for selected remedial technologies and their effectiveness.

\section{D plume mapping and volumetrics}

Three-dimensional plume maps were produced for the tritium and TCE plumes emanating from the southwest corner of the Old Radioactive Waste Burial Ground (ORWBG).

\section{Methodology}

Plume shapes were obtained from a grid of 15 hand-drawn cross sections over the entire SWPA using 1994 Field Investigation Plan (FIP), well, and seepline data for tritium and TCE. Groundwater flow lines (Figure 1) were assessed in order to match contamination with the appropriate source area in the vicinity (i.e., ORWBG versus $H$ Area Seepage Basins), and to deduce the presence or absence of contamination between sample locations. The resulting cross-

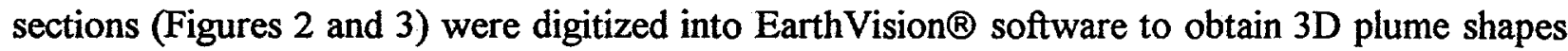
and volumetrics. Tritium concentration data were interpolated at a $200^{\prime}$ horizontal and $3^{\prime}$ vertical resolution onto a $19 \times 19 \times 213 \mathrm{D}$ grid conforming to the plume "centerline" or core surface. A vertical influence factor of 0.1 and nondetect value of $5 \mathrm{pCi} / \mathrm{ml}$ were specified. The resulting grid was then refined to a $28 \times 28 \times 413 D$ grid and smoothed. One smoothing pass was used for plume volumetrics and visualization of the $>20,000 \mathrm{pCi} / \mathrm{ml}$ and higher plumes. Three passes were used for visualization of the $>500 \mathrm{pCi} / \mathrm{ml}$ and lower plumes. TCE concentration data were interpolated at a $200^{\prime}$ horizontal and $8.3^{\prime}$ vertical resolution onto a $19 \times 19 \times 193 \mathrm{D}$ orthogonal (nonconformal) grid. Following mesh refinement, 2 smoothing passes were used for the $>40 \mathrm{ppb}$ and higher plume volumetrics and visualization, while 4 passes were used for the $>10 \mathrm{ppb}$ plume.

Results

Three-dimensional tritium plume maps were created for the $>20,000 \mathrm{pCi} / \mathrm{ml}$, (Figure 4,5 , and 6 ), $>500 \mathrm{pCi} / \mathrm{ml}$ (Figure 7), and $>50 \mathrm{pCi} / \mathrm{ml}$ concentration levels. Three-dimensional TCE plume maps were created for the $>200 \mathrm{ppb}$ (Figure 9), $>40 \mathrm{ppb}$ (Figures 10, 11, and 12), and the $>10$ $\mathrm{ppb}$ (Figure 13) concentrations levels. Volumetric calculations (plume volume and contaminant mass/activity) were performed for both the tritium and TCE 3D plumes and are summarized in Table 1. Plume vertical thickness ranges are also given. The $3 \mathrm{D}$ tritium plume maps and volumetrics show that about $63 \%$ of the total activity resides in a $<20^{\prime}$ thick layer above the "tan clay" confining zone comprising about $12 \%$ of the $>50 \mathrm{pCi} / \mathrm{ml}$ plume by volume.

\section{Benefits}

The remedial technology evaluation utilizing 3-D plume shapes based on field data will assist in reducing the uncertainty of the volume and concentration of the plume(s). This will be beneficial by assisting in the remedial design of the selected technology and ultimately will reduce remediation costs. For example, the tritium 3D mapping results suggest a depth discrete 
extraction system aimed at treating $63 \%$ of the activity but only $12 \%$ of the groundwater in the $>50 \mathrm{pCi} / \mathrm{ml}$ plume.

\section{Remedial scenario design and effectiveness}

Various remedial scenarios were designed to provide data for an economic analysis of alternatives, and then analyzed to determine their effectiveness. The technologies considered fall into four categories: no action, vertical barriers, pump-treat-reinject, and vertical recirculation wells.

\section{Methodology}

For each technology, computer simulation and analysis were performed to create a reasonably optimized, preliminary design. Key design parameters were compiled for input to an economic analysis of alternatives. Example parameters include the number, location, and pumping rates of extraction wells. Early work is reported in Appendix A. Then each design was simulated using the FACT groundwater flow and contaminant transport code to estimate the reduction in tritium discharge to Fourmile Branch that would result from employing the technology. These effectiveness estimates are based on the simulated 1996 tritium plume from the current FACTbased, ORWBG model (Flach et al., 1996). For all scenarios, the ORWBG is assumed to be capped and the southwest sedimentation basin in place beyond 1996.

\section{No action}

The no action scenario includes the planned interim burial ground cap and southwest sedimentation basin and serves as the baseline for the remedial scenarios that follow. Predicted tritium discharge to Fourmile Branch is shown Figure 14 and compared to the case of no ORWBG cap and southwest sedimentation basin.

\section{Vertical barriers}

Figure 15 illustrates the final vertical barrier configuration considered, and an outline of the $>500$ and $>20,000 \mathrm{pCi} / \mathrm{ml}, 3 \mathrm{D}$ tritium plumes from Figures 4 and 7 against a backdrop of the simulated plume from Flach et al. (1996). The barrier extends from the ground surface to the top of the Gordon confining unit (green clay), because earlier analysis indicated that a barrier down to the "tan clay" confining zone would be relatively ineffective (Appendix A). The linear footage of barrier is approximately 4000'. The effectiveness result for a vertical barrier without and with a surface cap over the barrier to reduce infiltration are shown in Figure 16. The barrier is effective in preventing upstream tritium from reaching surface water, but tritium between the barrier and Fourmile Branch continues to discharge. The net effect is about a $50 \%$ reduction in tritium discharge. 


\section{Pump, treat (VOC) and reinject}

In order to minimize future tritium discharge to surface waters, extraction wells were located just upgradient of the groundwater seepline along the old F-area effluent ditch as shown Figure 17. Injection wells were placed just south of $\mathrm{E}$ Road, in order to keep reinjected tritiated water from crossing the current groundwater divide while maximizing the distance between extraction and injection. For reference, the $>20,000 \mathrm{pCi} / \mathrm{ml}$ tritium and VOC hot-spot plumes (Figs. 4 and 9) are shown in Figure 17. Three levels of capture were considered: Upper and Lower Water Table (Upper Three Runs aquifer), Upper Water Table ("upper" zone of UTR aquifer), and "hot layer" extraction within the Upper Water Table aquifer zone. In each case, extraction with and without reinjection is considered. In order to resolve the detailed flow field around extraction and reinjection wells, a refined mesh between the burial ground and seepline was used as shown in Figure 17. Otherwise, the model is the essentially the same as Flach et al. (1996). For reference, outlines of the three-dimensional $>20,000 \mathrm{pCi} / \mathrm{ml}$ tritium, $>200 \mathrm{ppb}$ TCE and $>100 \mathrm{ppb}$ PCE plumes are shown in Figure 17.

Upper and Lower Water Table capture: In this scenario, well screens are placed above and below the "tan clay" confining zone at 6 areal locations with the objective of capturing essentially the entire $>50 \mathrm{pCi} / \mathrm{ml}$ tritium plume. The final scenario considered is similar to that documented in Appendix B, the difference being that a sixth well was added to the Lower Water Table, and the screen zones in this region were shortened from a nominal $40^{\prime}$ to $20^{\prime}$. The intent had been to reduce the overall pumping rate from the Lower Water Table and focus capture in the upper portion of the aquifer zone without compromising capture width. However, the additional well resulted in a net increase in pumping rate. Additional work is needed to create an optimal design. For extraction only, the total pumping rate for the 12 screen zones is $130 \mathrm{gpm}$. The capture zones for the upper and lower extraction screen zones are depicted in Figures 18 and 19, and Figure 20 illustrates the effectiveness of the technology. Analogous results for extraction with reinjection are presented in Figures 21 through 24 (see Figure 20 for effectiveness). The total pumping rate increases to $191 \mathrm{gpm}$ for reinjection because groundwater injected into the capture zone must be withdrawn by the extraction wells. Note that a significant fraction of reinjected groundwater bypasses the extraction wells. The amount of bypass flow is equal to the amount of recharge within the capture zone. The effectiveness of both scenarios is similar to that for vertical barriers, but lower.

Upper Water Table capture: In this scenario, well screens are placed above the "tan clay" confining zone at 6 locations to capture contaminated groundwater in the Upper Water Table. The final scenario considered is similar to that documented in Flach (1996), the difference being that a sixth well was added to the Upper Water Table. The additional screen was added because the well efficiencies in Appendix B may be optimistic. For the case of extraction only, the total pumping rate for the 6 screen zones is $69 \mathrm{gpm}$. The capture zone is depicted in Figure 25, and Figure 26 illustrates the effectiveness of the technology. Analogous results for extraction with reinjection are presented in Figures 27 and 28 (see Figure 26 for effectiveness). The total pumping rate for reinjection increases to $89 \mathrm{gpm}$. The effectiveness estimates depicted in Figure 26 are believed to significantly underpredict the reduction in tritium discharge that would be realized. The reason is that the model simulated plume is thicker in the vertical direction, and 
$50 \%$ or more lies below the "tan clay" confining zone. In contrast, 3D mapping of field data discussed above indicates that most of the tritium activity lies above the "tan clay". Therefore, Upper Water Table capture should amount to complete plume capture and yield tritium discharge reductions closer to that shown in Figure 20.

"Hot layer" capture: The 3D tritium plume maps (Figures 4 through 6) and volumetrics (Table 1) show that about $63 \%$ of the total activity resides in a $<20^{\prime}$ thick "hot layer" above the "tan clay" confining zone comprising about $12 \%$ of the $>50 \mathrm{pCi} / \mathrm{ml}$ plume by volume. The cost-benefit ratio for pump-treat-reinject can be minimized by extracting only from this hot layer within the Upper Water Table aquifer zone. Depth discrete extraction can be accomplished with relatively closely spaced, partially penetrating well screens, each pumping at a low flowrate. The computational mesh of the ORWBG model, used to perform the capture zone analyses above, is too coarse to investigate hot layer capture. Therefore a special purpose model was created to investigate the three-dimensional flow field and capture zone around a partially penetrating well screen pumping at low rates. The model is designed to be representative of conditions between the burial ground and F-effluent ditch seepline. The computational mesh extends $2000^{\prime}$ in length from the ORWBG to the F-effluent ditch seepline and is $250^{\prime}$ wide by $40^{\prime}$ high. The water level is $40^{\prime}$ above the "tan clay" at the ORWBG and $20^{\prime}$ at the seepline. The horizontal conductivity is $19 \mathrm{ft} / \mathrm{d}$, consistent with larger ORWBG model. Recharge is assumed to be $15 \mathrm{in} / \mathrm{yr}$, and two-thirds this amount is allowed to leak through the "tan clay".

Initial scenarios of a single well screen $5^{\prime}$ in length and pumping at $1.5 \mathrm{gpm}$ yielded an upstream capture zone of about $100^{\prime}$ wide by $16^{\prime}$ high. This lead to a second series of scenarios for multiple $5^{\prime}$ screens placed 50' apart and pumping at $1.1 \mathrm{gpm}$. As shown in Figure 29, the upstream capture thickness is about $20^{\prime}$. For reinjection, somewhat higher pumping rates would be required. Hotlayer capture and reinjection of the southwest tritium plume could be accomplished with a 1000' capture line of 20 screens ( $5^{\prime}$ length) placed at $50^{\prime}$ intervals as shown in Figure 30 . Each extraction well would pump at less than $1.5 \mathrm{gpm}$. Table 2 lists the site coordinates of the wells depicted in Figure 30. The total pumping rate would be half that for complete Upper Water Table capture, but achieve most of the effectiveness.

Wetland/seepline impacts: The greatest impact to the seepline and wetlands in the vicinity of the old F-area effluent ditch occurs for Upper and Lower Water Table capture without reinjection. This scenario produces the largest net reduction in groundwater discharge to surface. Groundwater scenarios predict the seepline will recede about $150 \mathrm{ft}$ down the F-area effluent ditch. The predicted seepage area of the old F-area effluent ditch is slightly narrower, most notably along the upper $500 \mathrm{ft}$. Elsewhere seepline perturbations are insignificant.

\section{Vertical recirculation wells}

In-situ treatment of two VOC hot-spots (Fig. 9) using two vertical recirculation wells was considered. No other remedial technology that would disturb baseline groundwater flow (e.g. pump-treat-reinject) was assumed to be present. Capture zone analysis results for the extraction (lower) and injection (upper) screen zones are shown in Figures 31 and 32. Vertical recirculation 
wells would adversely affect "hot layer" tritium capture in later years because tritium would be spread over the entire thickness of the Upper Water Table.

\section{References}

Amidon, M.B., personal communication.

Dixon, K.L. and C.L. Cummins, Westinghouse Savannah River Company, 1994, Quarterly Sampling of the Wetlands along the Old F-Area Effluent Ditch (U). WSRC-TR-94-0365, Westinghouse Savannah River Company, Savannah River Site, Aiken, SC. May 1994.

Flach, G. P., L. L. Hamm, M. K. Harris, P. A. Thayer, J. S. Haselow, and A. D. Smits, 1996, Groundwater flow and tritium migration from the SRS Old Burial Ground to Fourmile Branch, WSRC-TR-96-0037.

Westinghouse Savannah River Company, 1995, Burial Ground Complex Field Investigation Preliminary Data Report \#1. (U). WSRC-RP-94-1286, Westinghouse Savannah River Company, Savannah River Site, Aiken, SC. January 1995. 
Table 1. Volumetric results of $3 \mathrm{D}$ plume mapping study.

\begin{tabular}{|l|c|c|c|}
\hline & $\begin{array}{c}|c| \\
>20,000 \mathrm{pCi} / \mathrm{ml}(\mathrm{ACL}) \\
\mathrm{plume}\end{array}$ & $\begin{array}{c}>500 \mathrm{pCi} / \mathrm{ml} \text { (MCL) } \\
\mathrm{plume}\end{array}$ & $\begin{array}{c}>50 \mathrm{pCi} / \mathrm{ml} \\
\mathrm{plume}\end{array}$ \\
\hline Activity $(103 \mathrm{Ci})$ & $\begin{array}{c}10.9 \\
(63 \% \text { of }>50 \mathrm{pCi} / \mathrm{ml} \text { plume })\end{array}$ & 17.1 & 17.3 \\
\hline Volume $(106 \mathrm{gal})$ & $\begin{array}{c}68 \\
(12 \% \text { of }>50 \mathrm{pCi} / \mathrm{ml} \text { plume })\end{array}$ & 405 & 586 \\
\hline $\begin{array}{l}\text { Thickness estimated } \\
\text { from cross-sections }(\mathrm{ft})\end{array}$ & $4-19$ & $15-50$ & $27-80$ \\
\hline
\end{tabular}

\begin{tabular}{|l|c|c|c|}
\hline & $>200 \mathrm{ppb}$ plume & $>40 \mathrm{ppb}$ plume & $\begin{array}{c}>10 \mathrm{ppb} \\
\text { plume }\end{array}$ \\
\hline Mass (kg) & .19 & 5.6 & 8.3 \\
\hline Volume (106 gal) & 1.7 & 150 & 500 \\
\hline $\begin{array}{l}\text { Thickness estimated } \\
\text { from cross-sections (ft) }\end{array}$ & $11-32$ & $7-55$ & $22-65$ \\
\hline
\end{tabular}


Table 2. Locations of extraction and reinjection wells for "hot layer" tritium capture.

\begin{tabular}{|l|ll|}
\hline Wells & SRS coordinates (E,N) \\
\hline Extraction & 53368.77 & 74004.86 \\
& 53429.68 & 74003.13 \\
& 53490.59 & 74001.41 \\
& 53551.50 & 73999.69 \\
& 53612.41 & 73997.97 \\
& 53673.32 & 73996.24 \\
& 53734.23 & 73994.52 \\
& 53795.14 & 73992.80 \\
& 53856.05 & 73991.07 \\
& 53916.96 & 73989.34 \\
& 53977.87 & 73987.63 \\
& 54038.78 & 73985.90 \\
& 54099.69 & 73984.18 \\
& 54146.18 & 73962.96 \\
& 54171.05 & 73912.49 \\
& 54195.92 & 73862.03 \\
& 54220.79 & 73811.57 \\
& 54245.66 & 73761.10 \\
& 54270.53 & 73710.64 \\
& 54295.40 & 73660.18 \\
\hline \multirow{5}{*}{ Injection } & 54362.55 & 74966.20 \\
& 54493.21 & 74869.59 \\
& 54643.19 & 74799.11 \\
& 54773.85 & 74702.50 \\
& 54923.84 & 74632.02 \\
& 55054.49 & 74535.41 \\
\hline
\end{tabular}




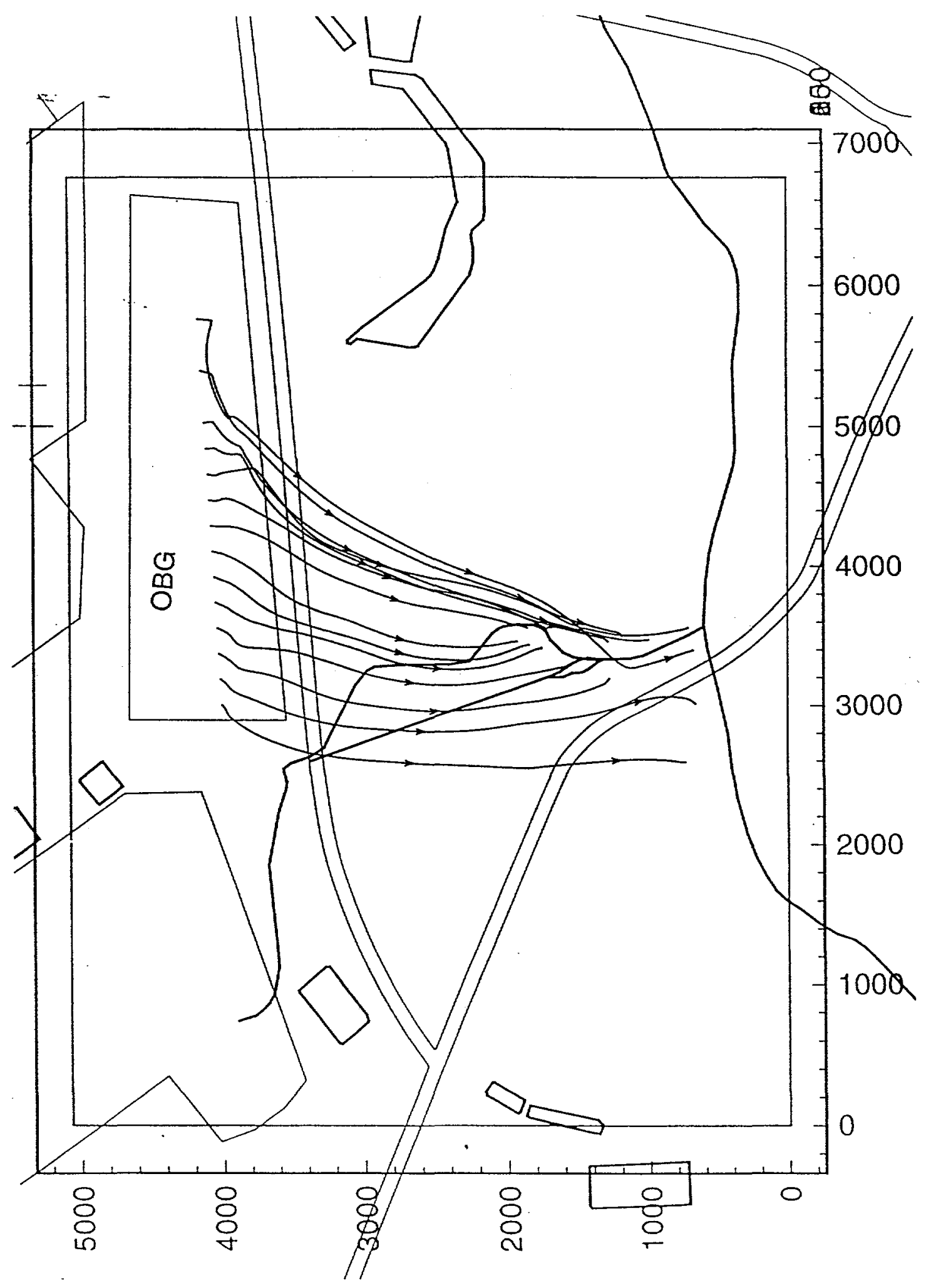

Figure 1. Predicted groundwater flowlines from the FACT numerical model 


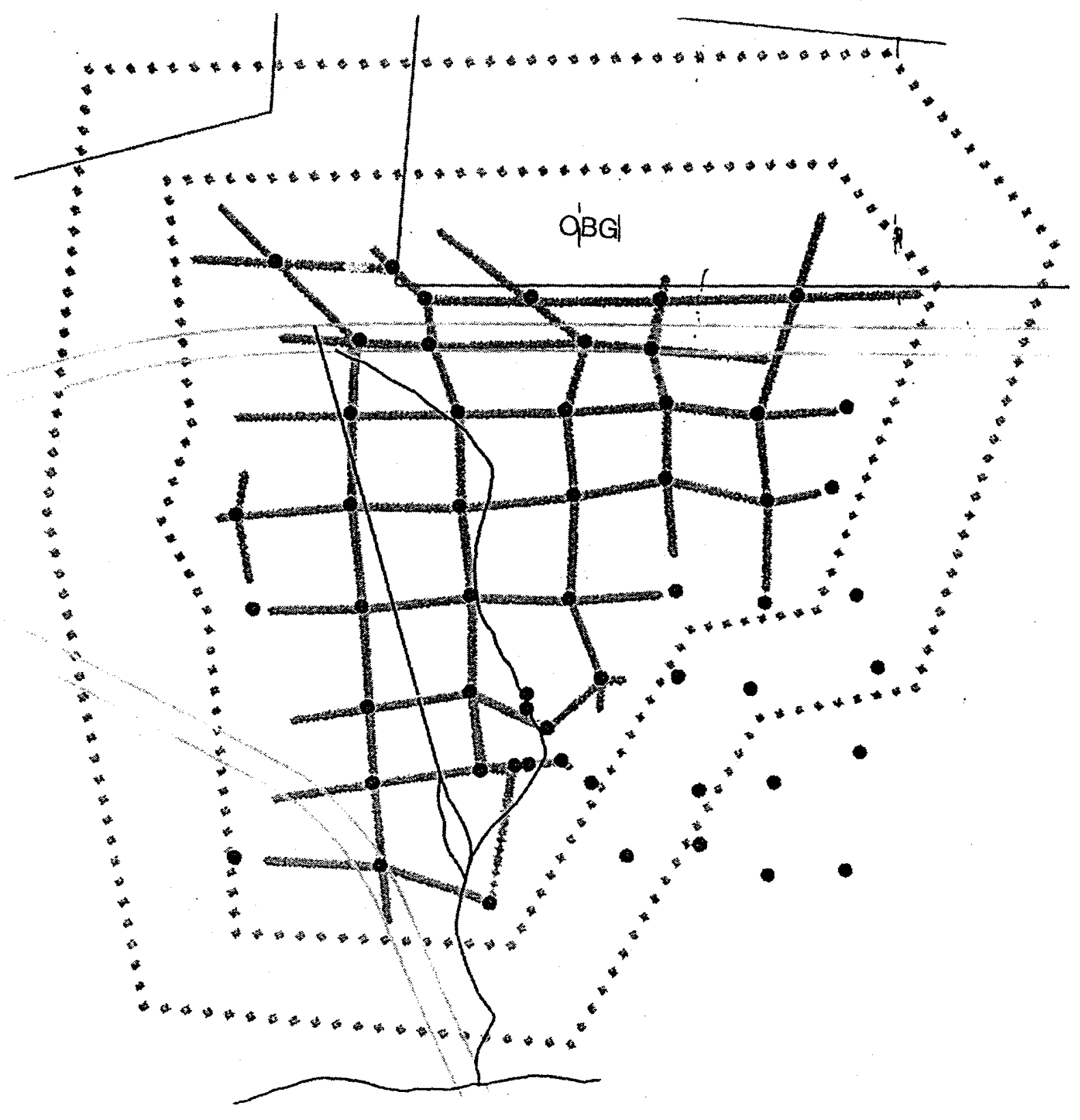

Figure 2. Cross-section grid - tritium plume 


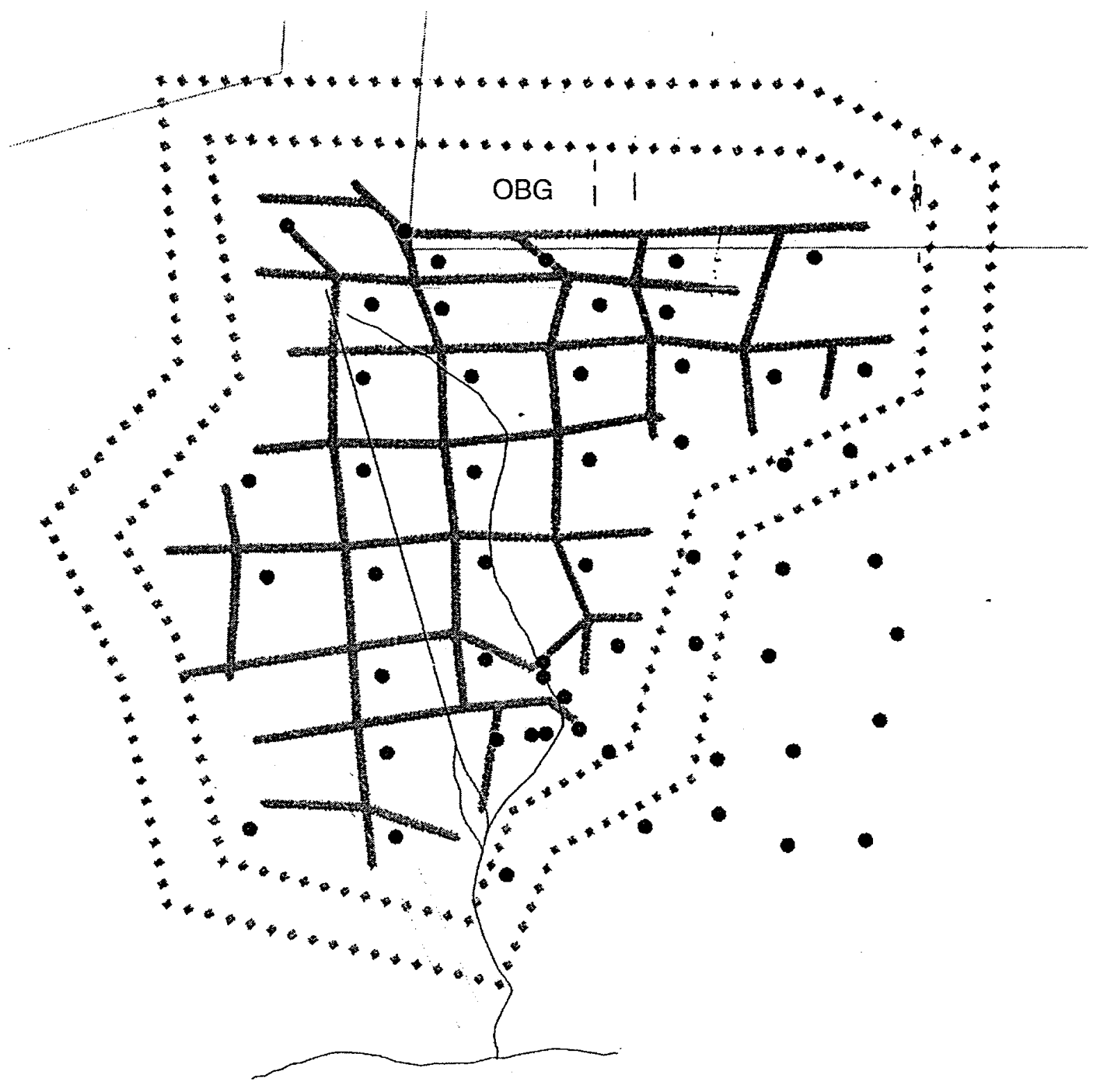

Figure 3. Cross-section grid - TCE plume 


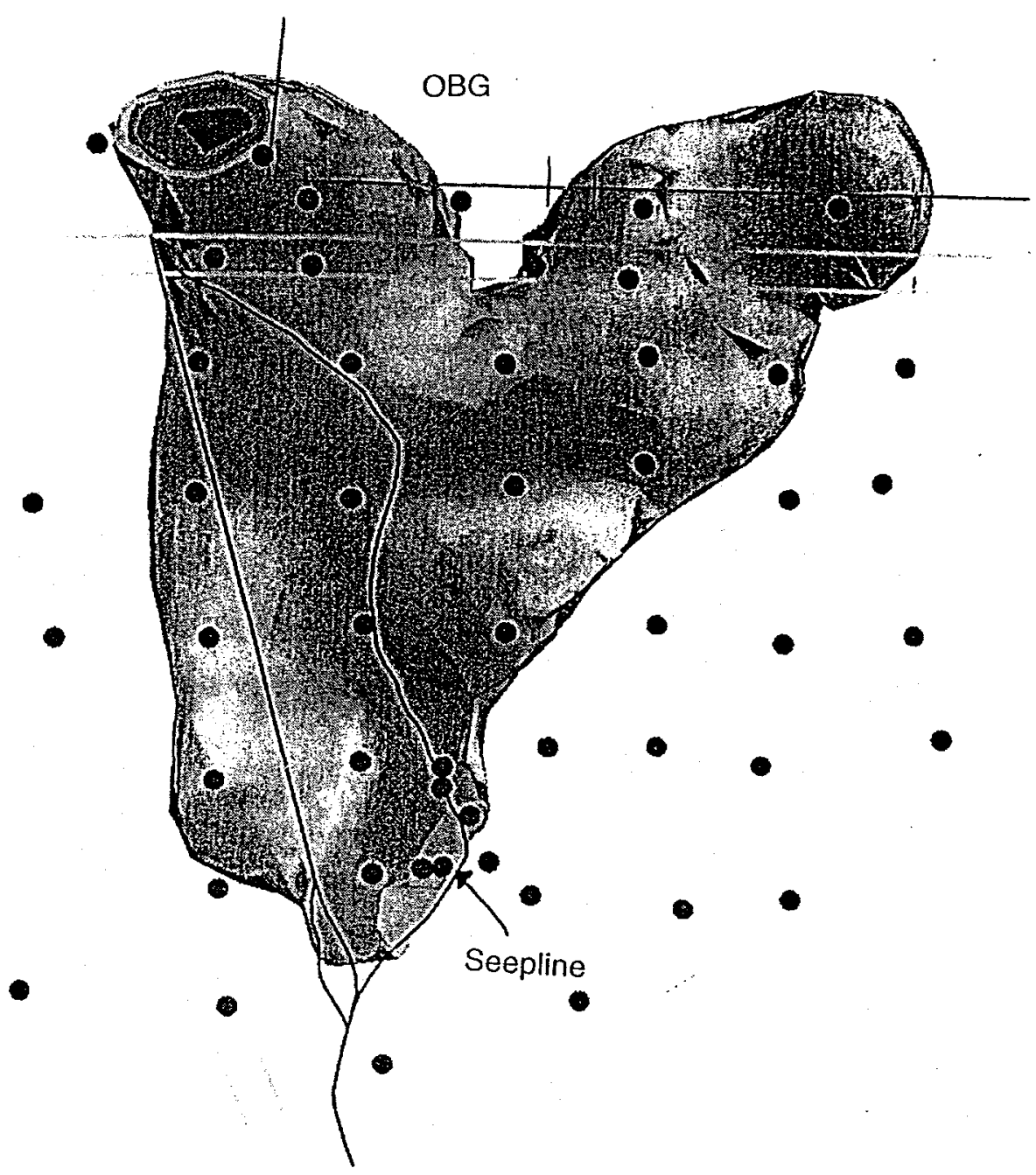

Figure 4. Plan view of tritium ACL plume $>20,000 \mathrm{pCi} / \mathrm{ml}$ 


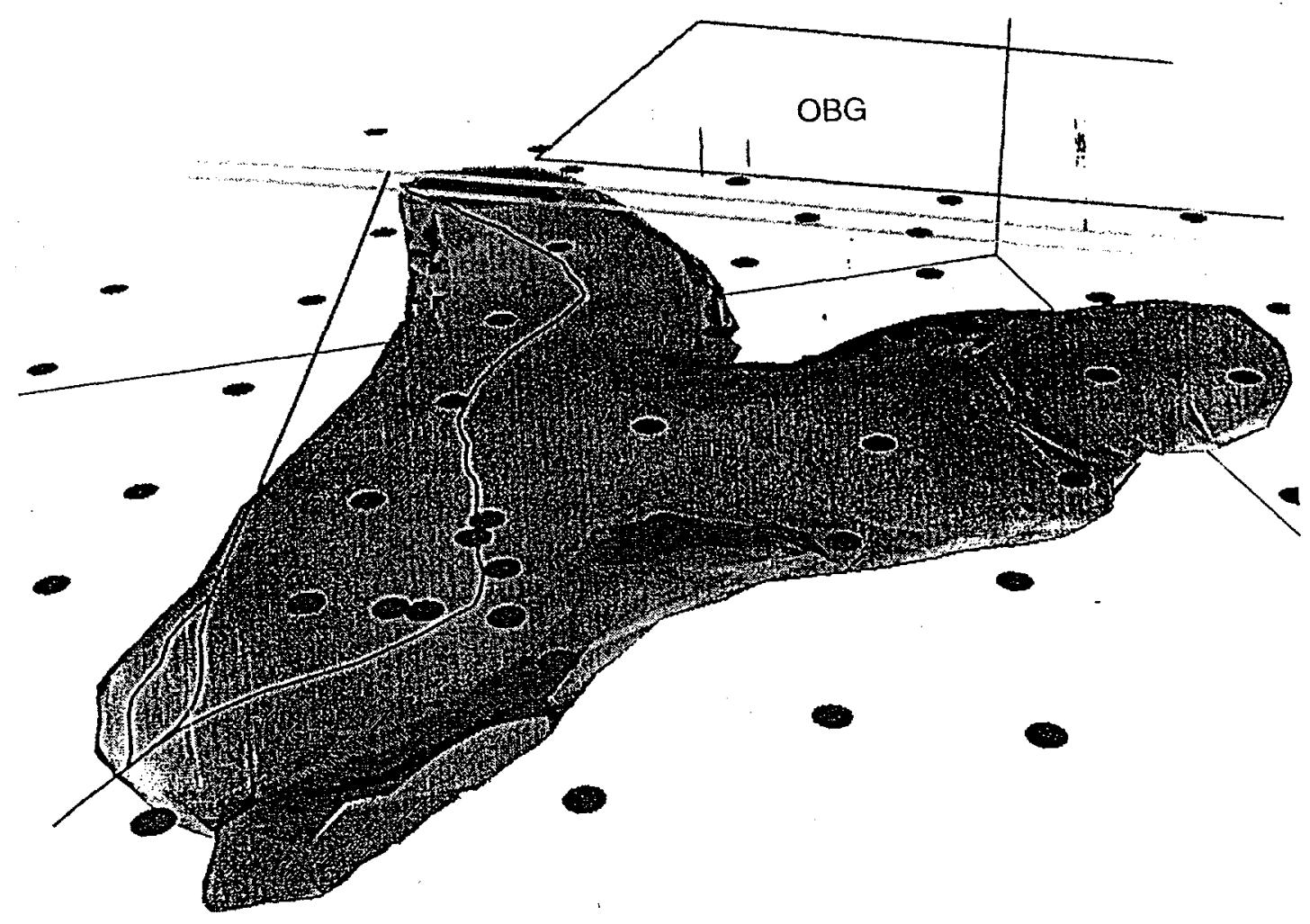

Figure 5. Side view (looking west) of Tritium ACL Plume $>20,000 \mathrm{pCi} / \mathrm{ml}$ 


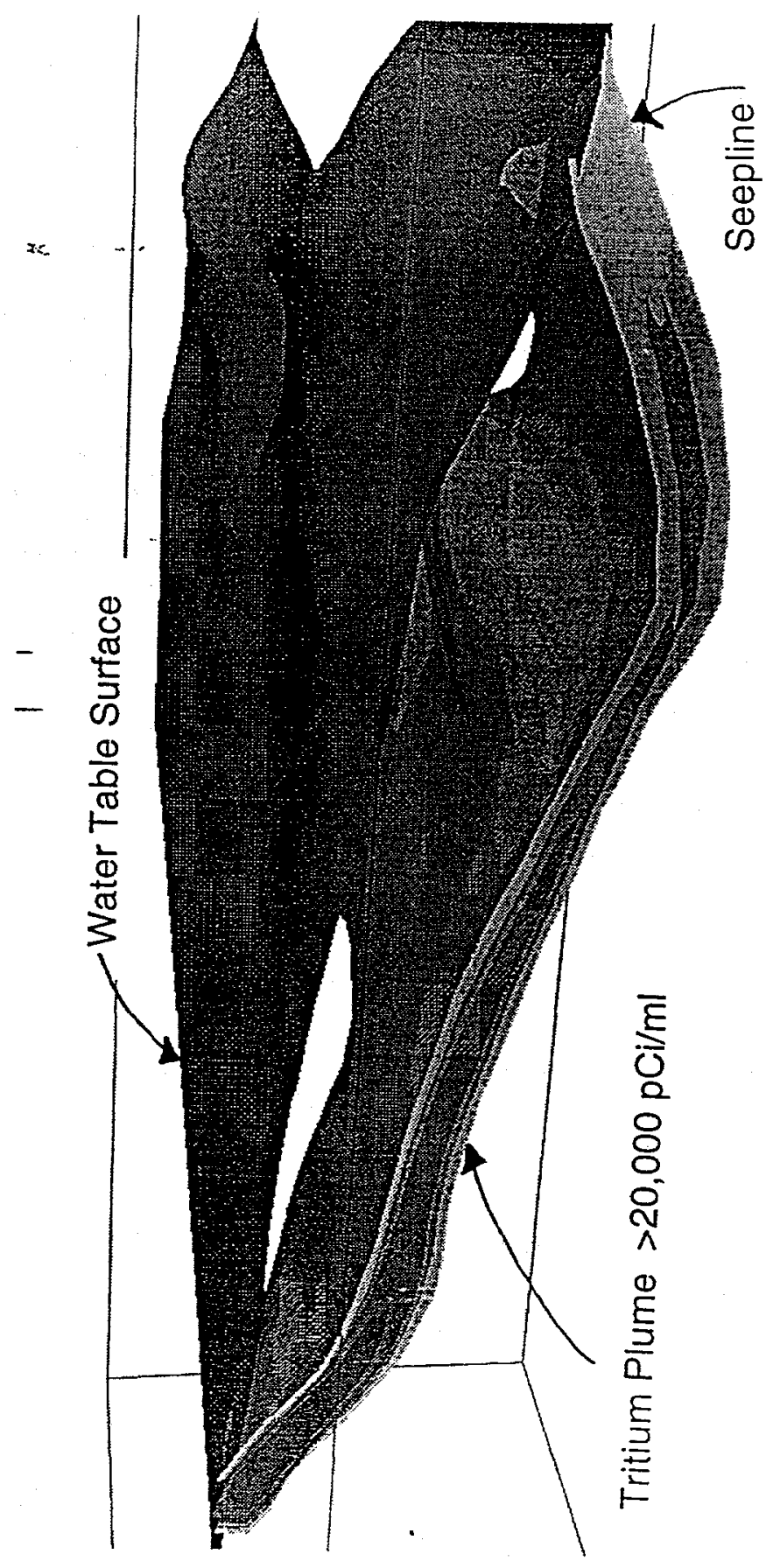

Figure 6. Cross-sectional view (looking east) of tritium ACL plume $>20,0000 \mathrm{pCi} / \mathrm{ml}$ with water table surface 


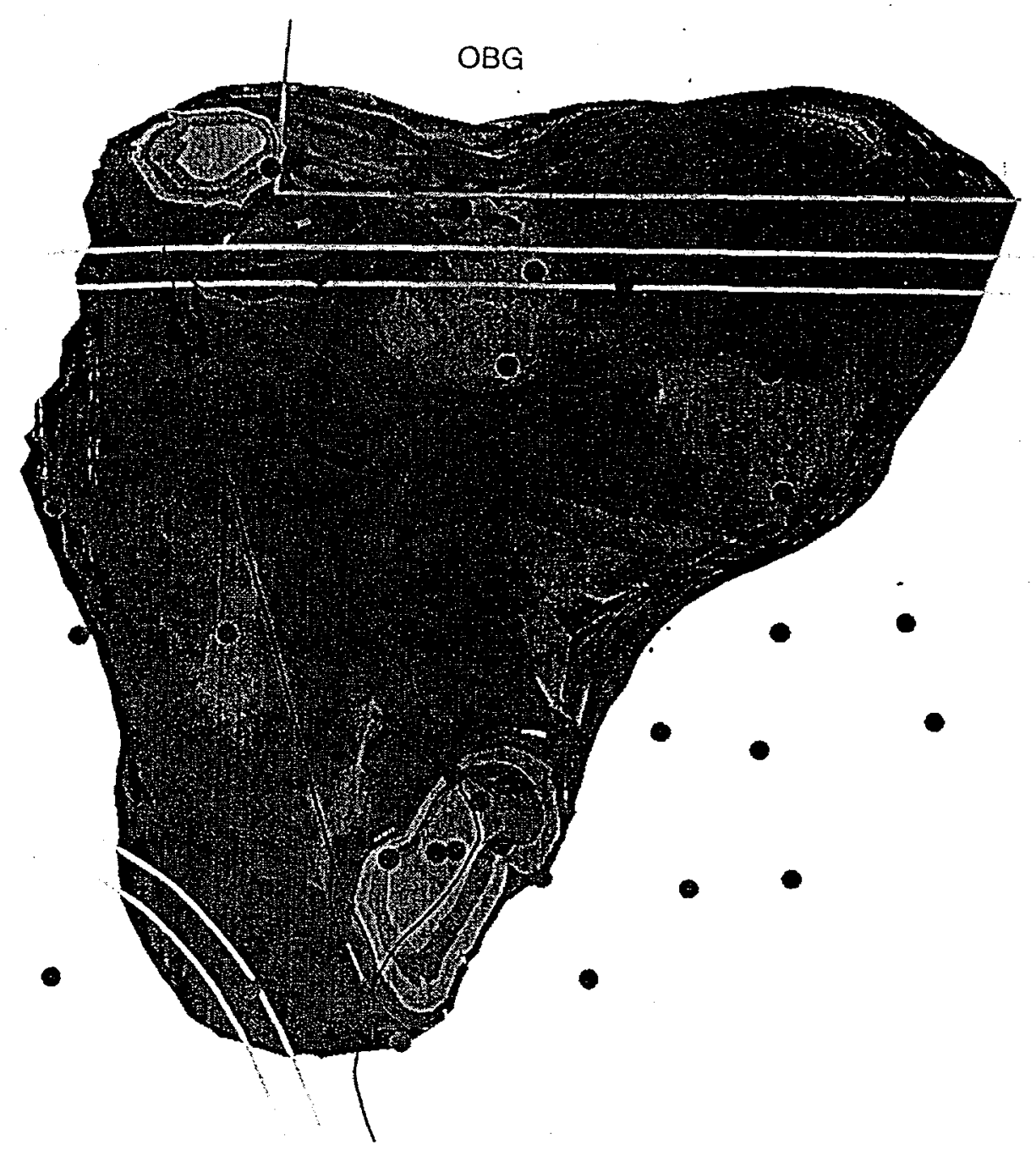

Figure 7. Plan view of tritium plume $>500 \mathrm{pCi} / \mathrm{ml}$ 


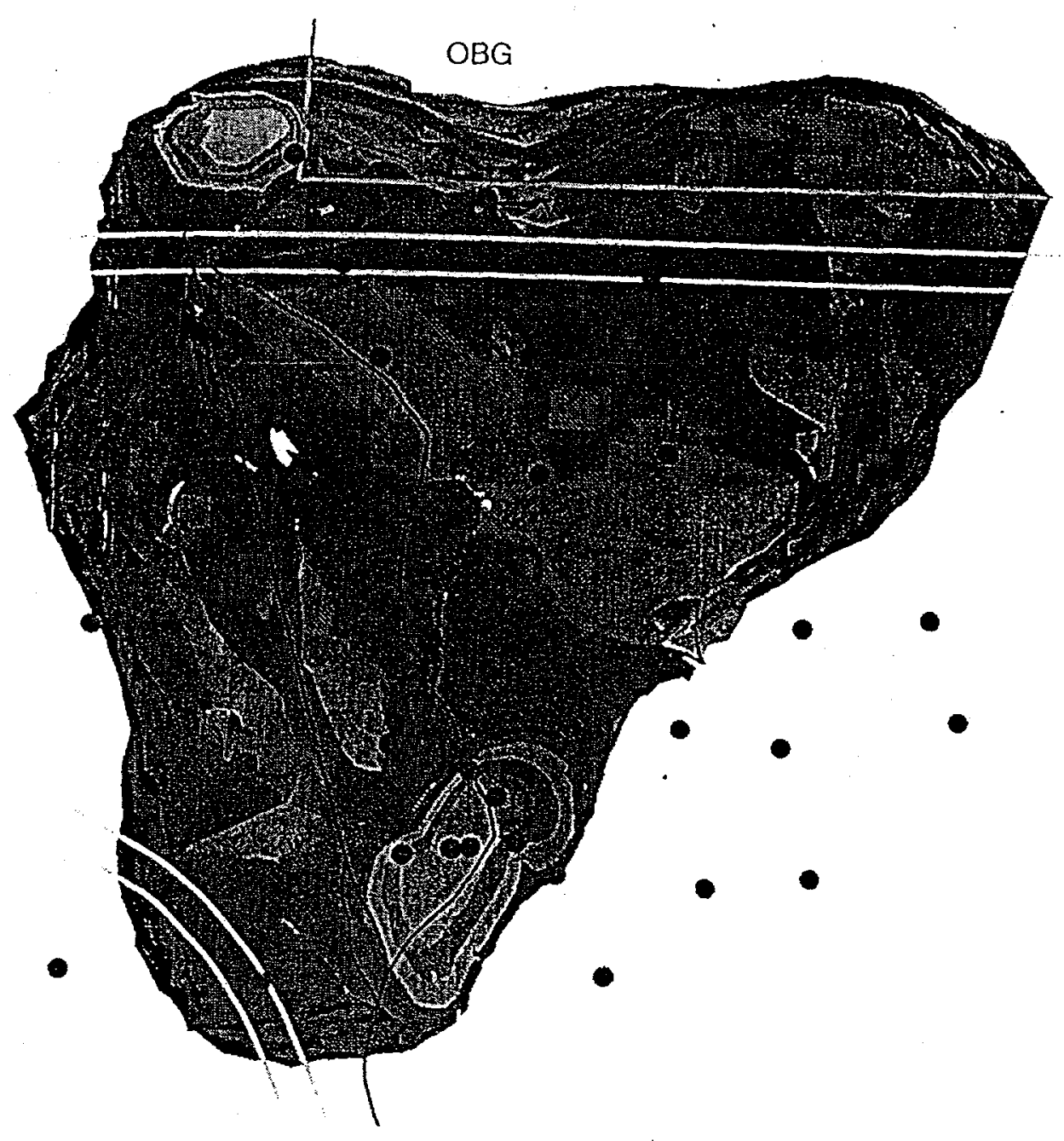

Figure 8. Plan view of Tritium Plume $>50 \mathrm{pCi} / \mathrm{ml}$ 


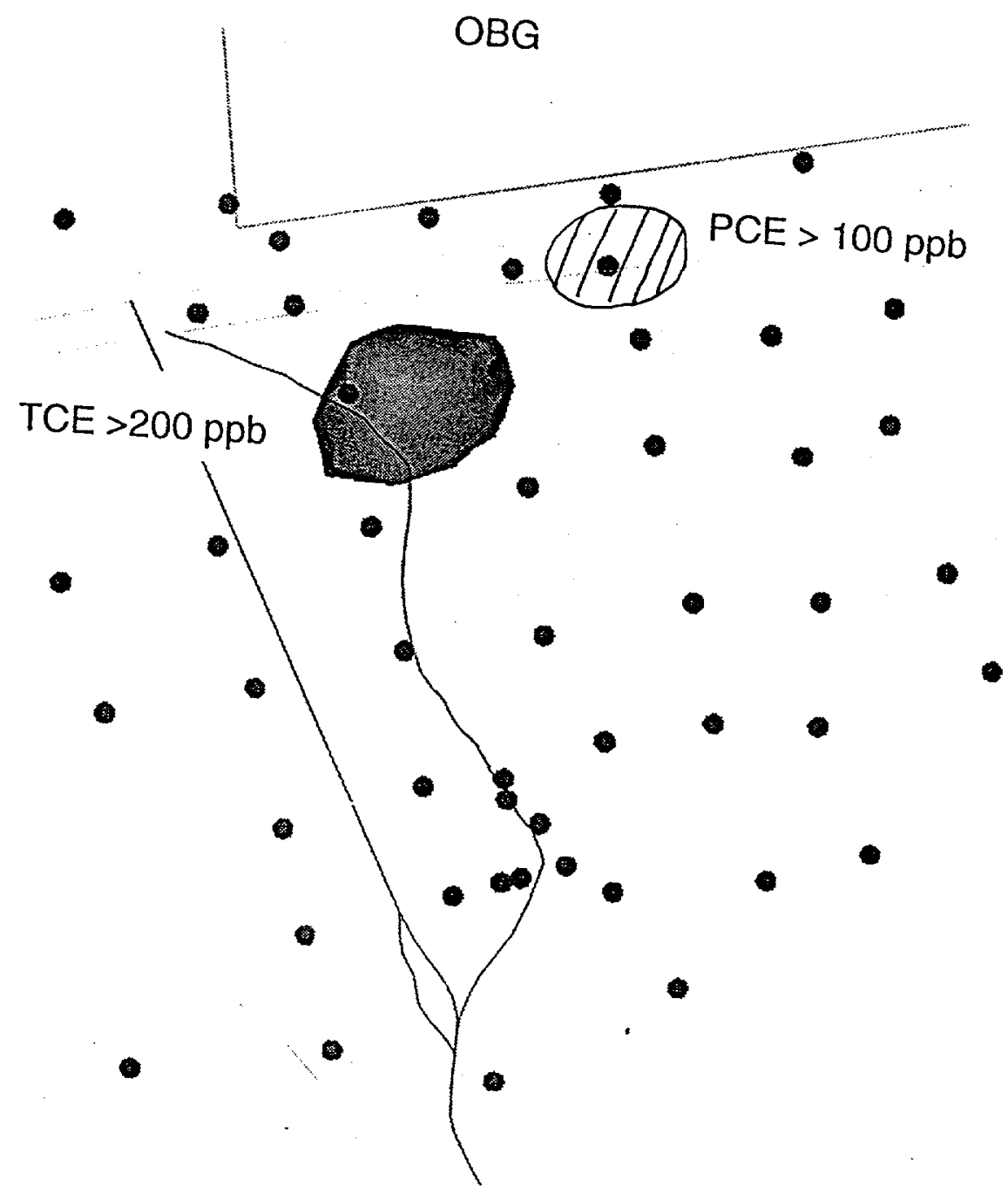

Figure 9. Plan view of TCE plume $>200 \mathrm{ppb}$ and PCE plume $>100 \mathrm{ppb}$ 


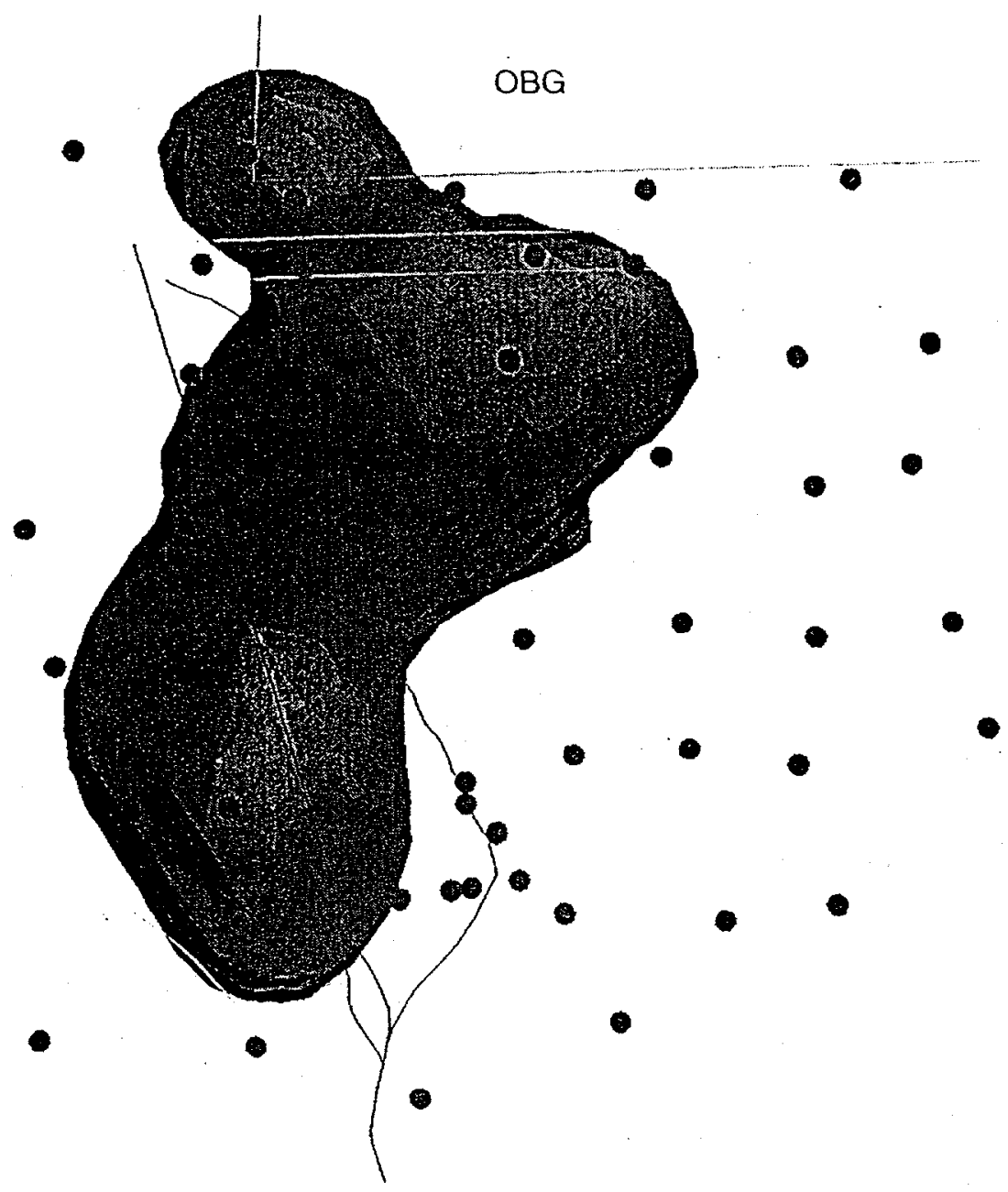

Figure 10. Plan view of TCE plume $>40 \mathrm{ppb}$ 


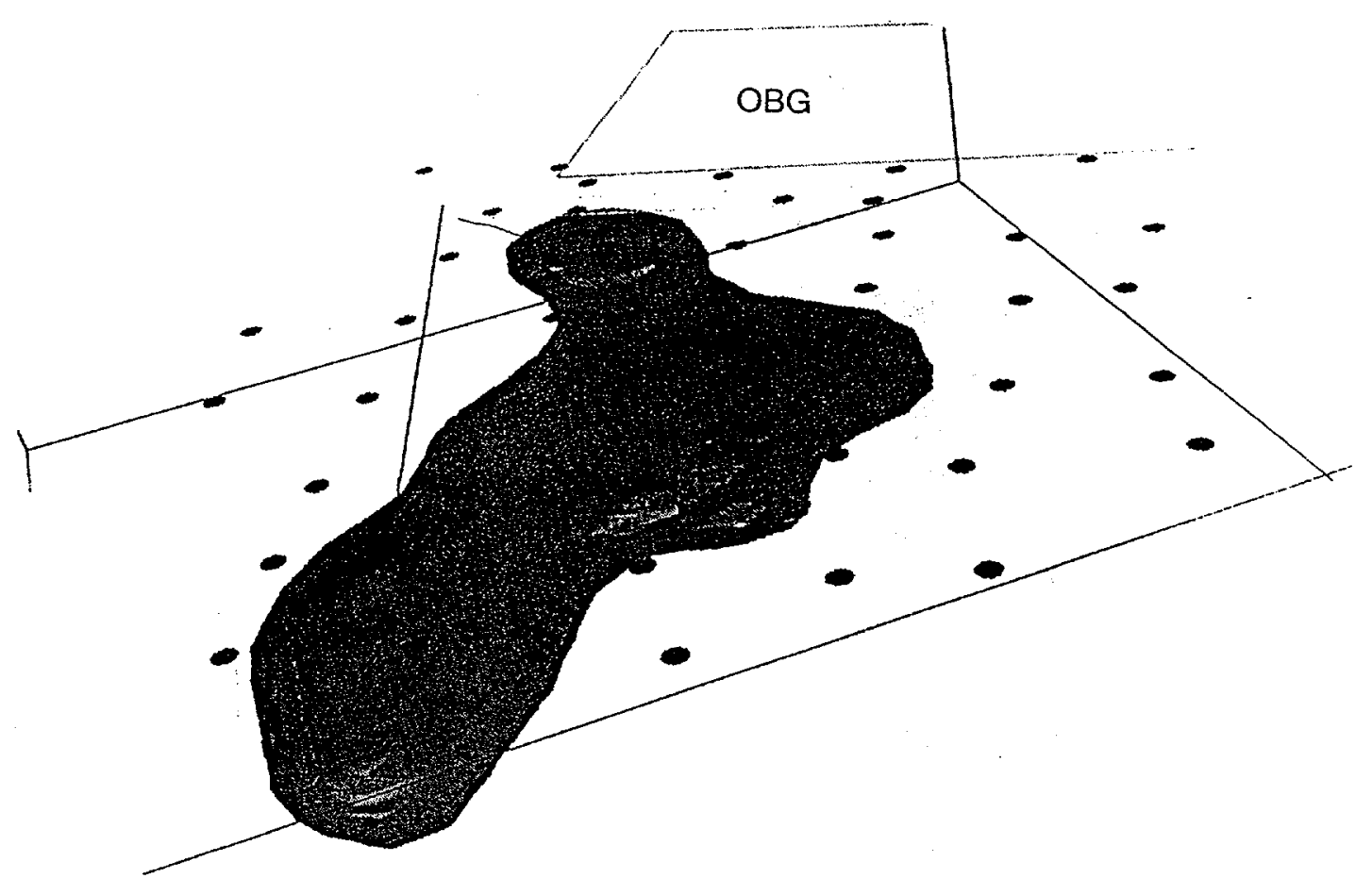

Figure 11. Side view (looking west) of TCE plume $>40 \mathrm{ppb}$ 


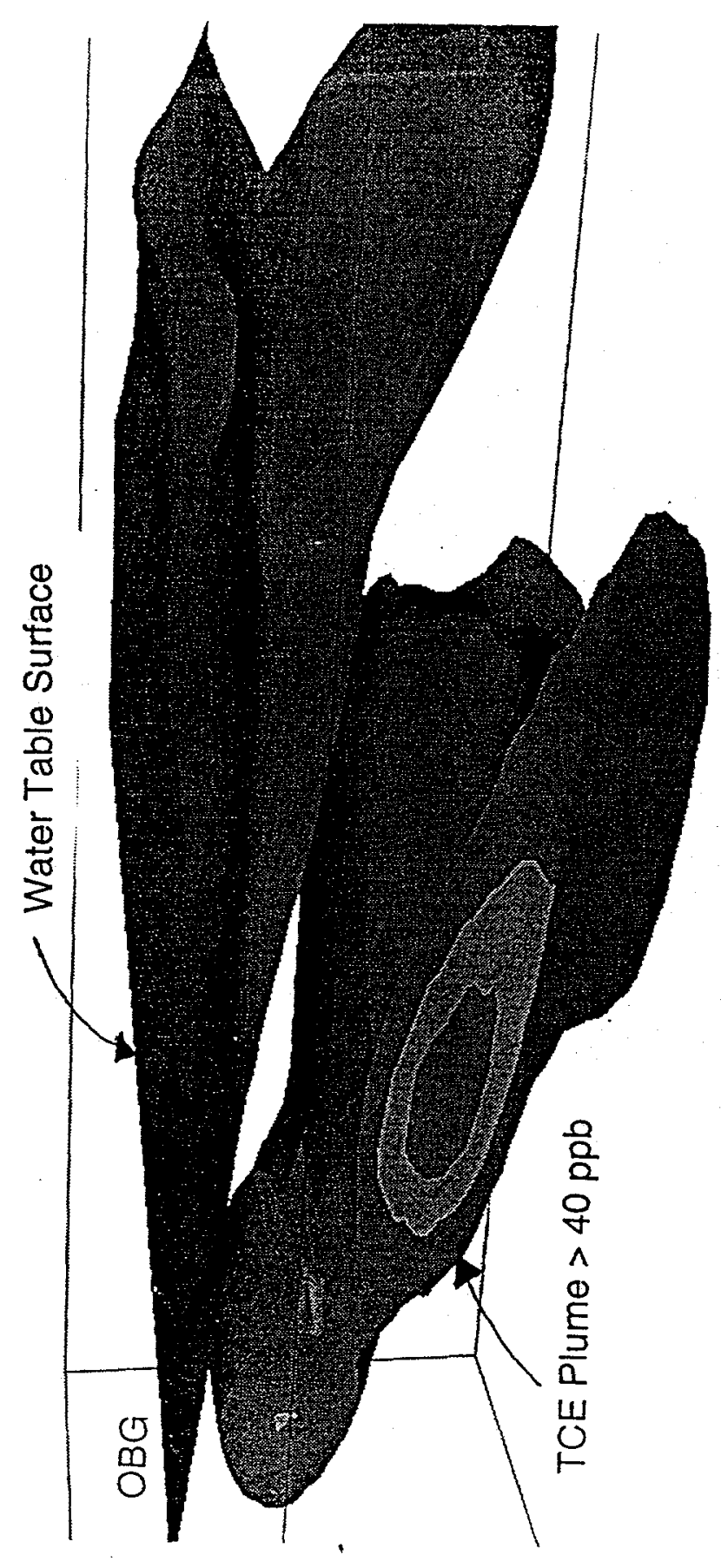

Figure 12. Cross-sectional view (looking east) of TCE Plume $>40 \mathrm{ppb}$ with water table surface 


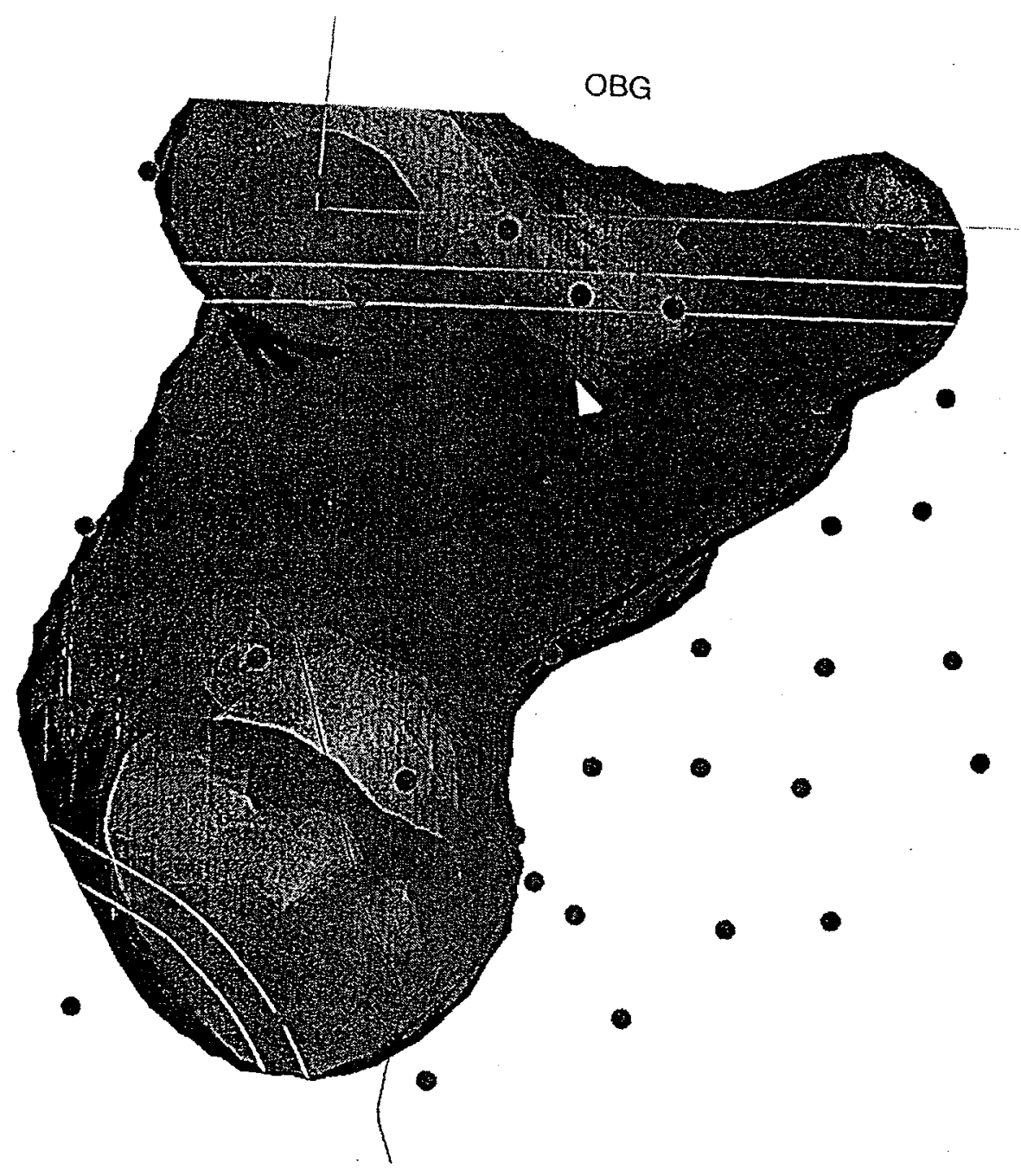

Figure 13. Plan view of TCE plume $>10 \mathrm{ppb}$ 


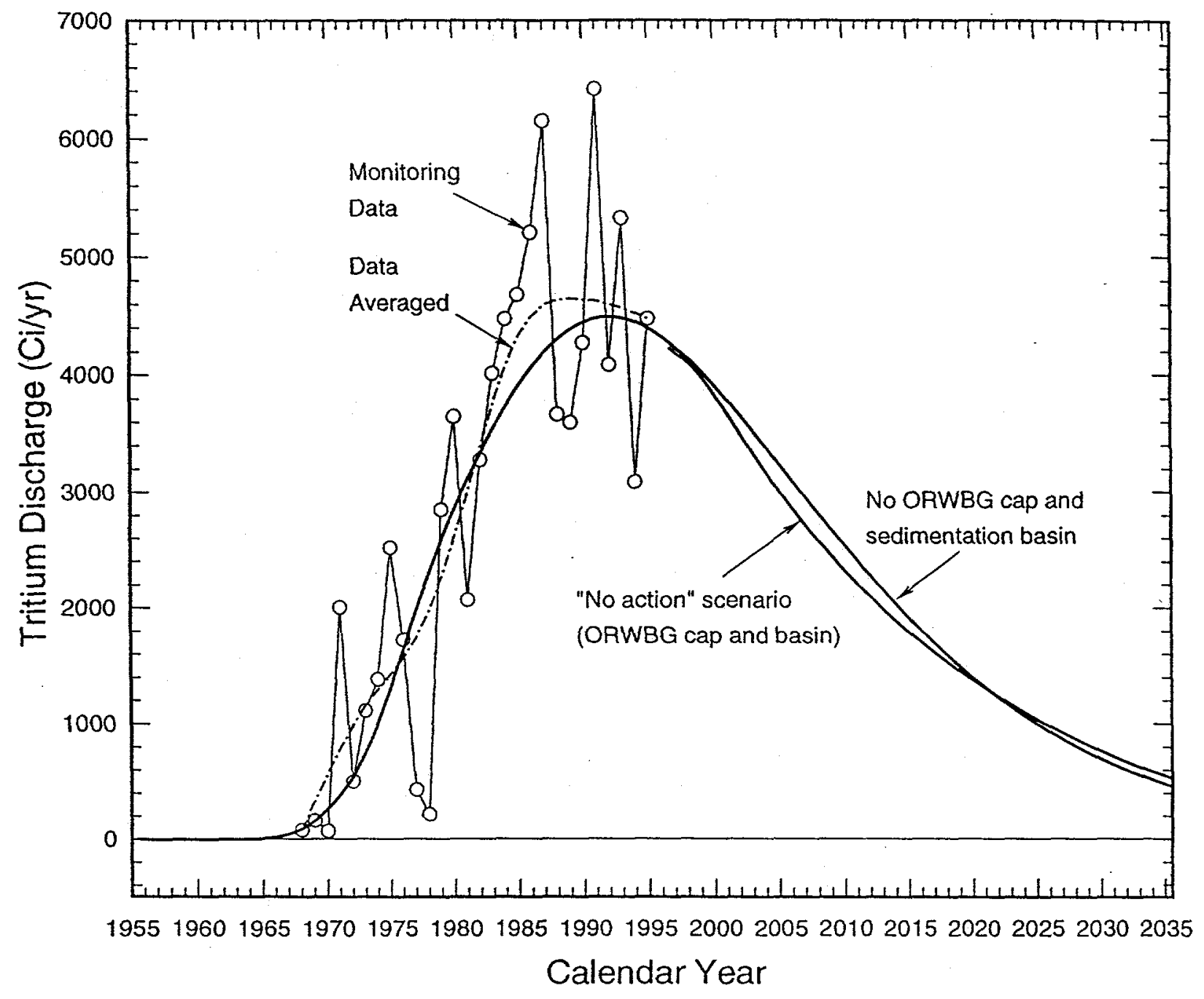

Figure 14. Tritium discharge for no action scenario 
Upper Water Table average concentration $(\mathrm{pCi} / \mathrm{ml})$

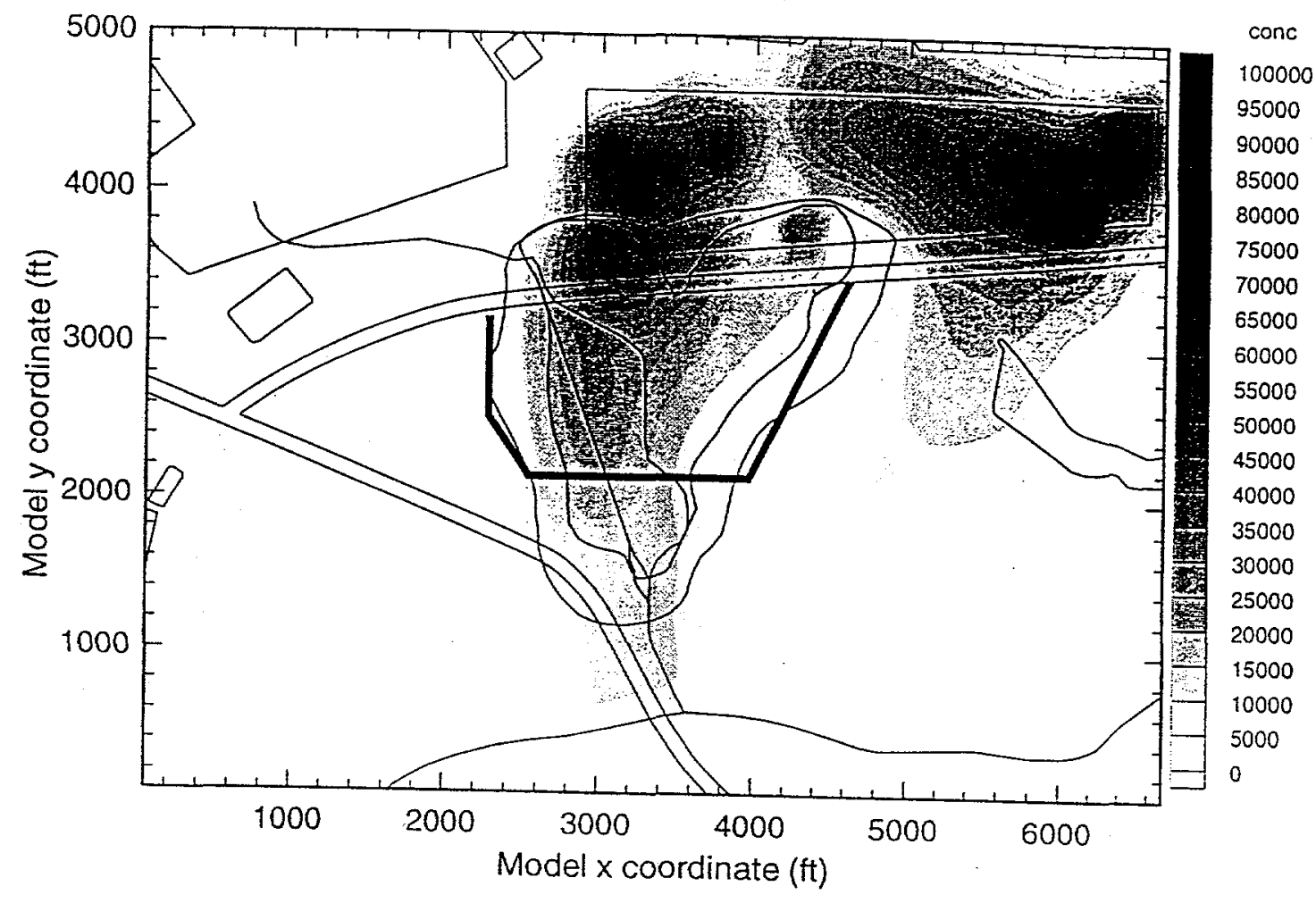

Figure 15. Vertical barrier configuration 


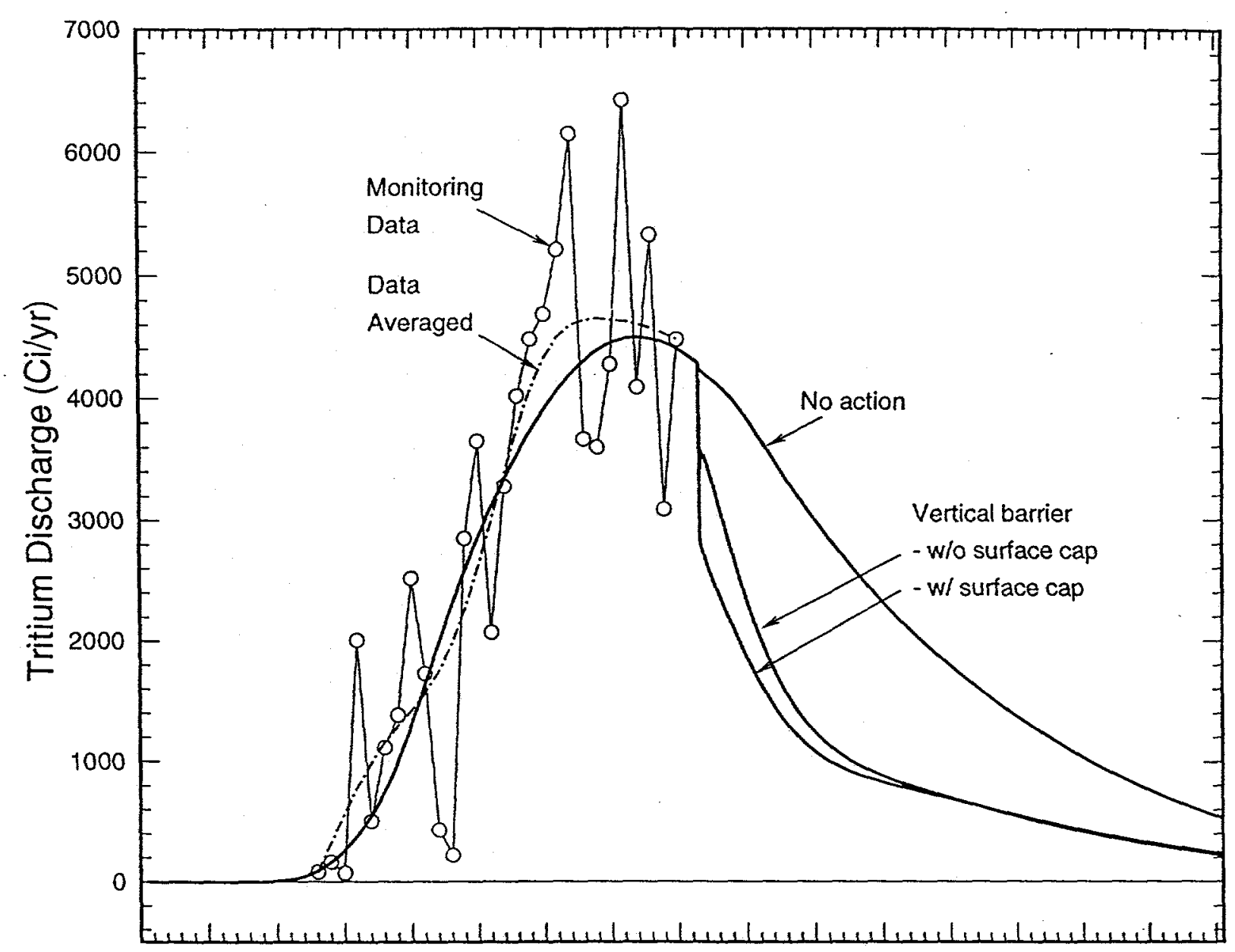

19551960196519701975198019851990199520002005201020152020202520302035

Calendar Year

Figure 16. Tritium discharge for vertical barrier scenarios 


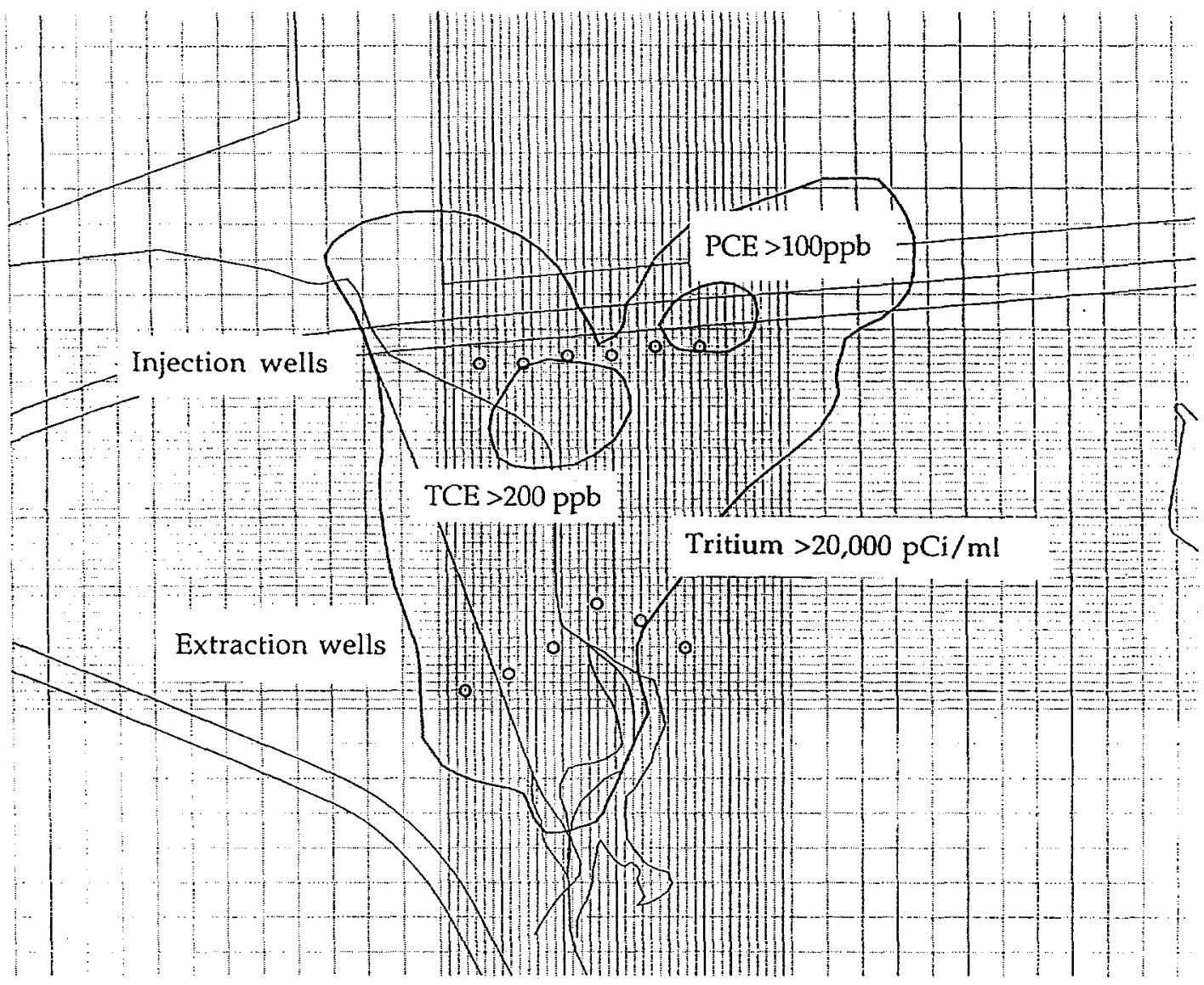

Figure 17. Location of wells for extraction and reinjection scenarios 


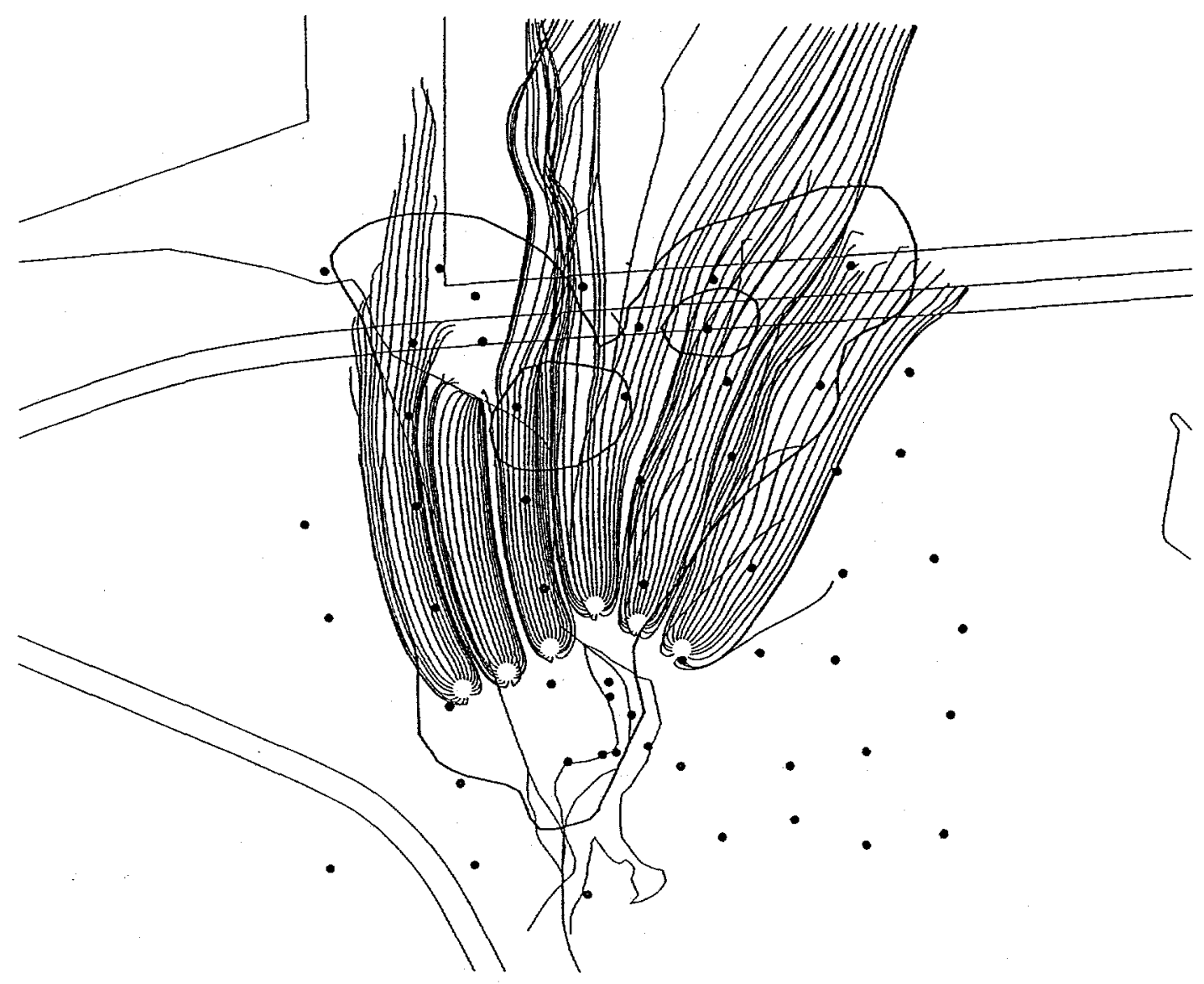

Figure 18. Capture zone within the "Upper Water Table" for well screens above and below the "Tan Clay Confining Zone" (200' elevation) 


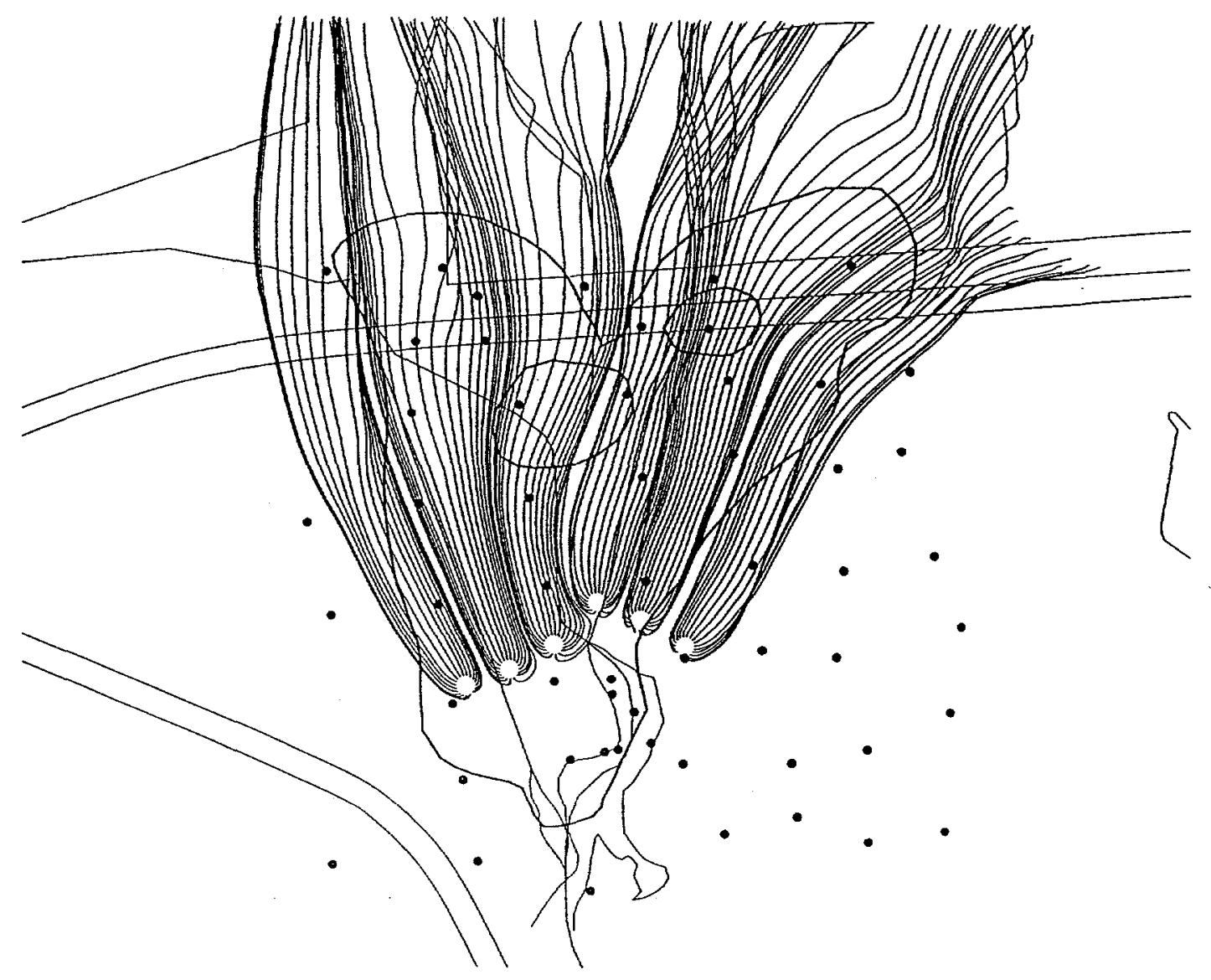

Figure 19. Capture zone within the "Lower Water Table" for well screens above and below the "Tan Clay Confining Zone" (180' elevation) 


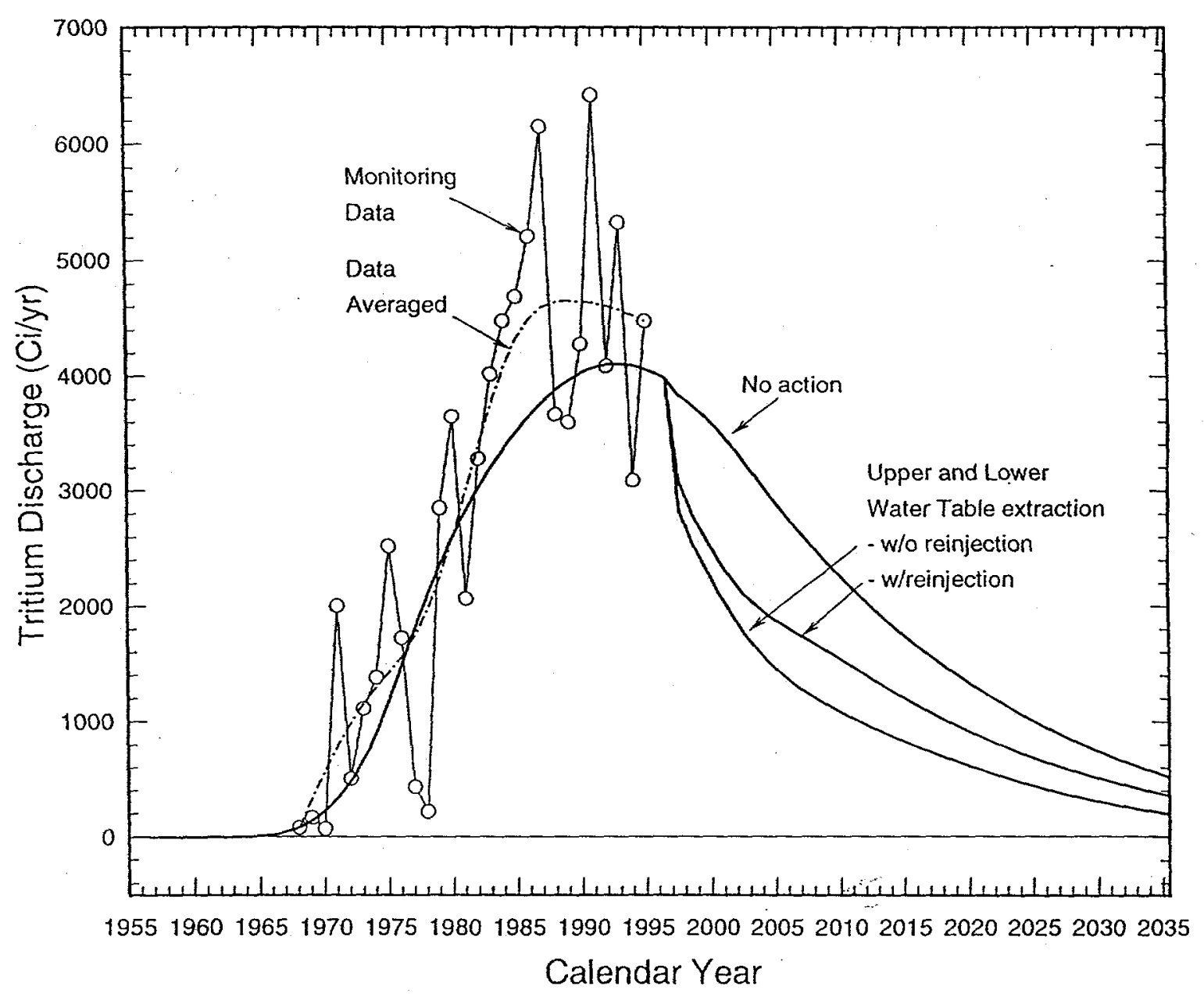

Figure 20. Tritium discharge for "Upper and Lower Water Table" capture 


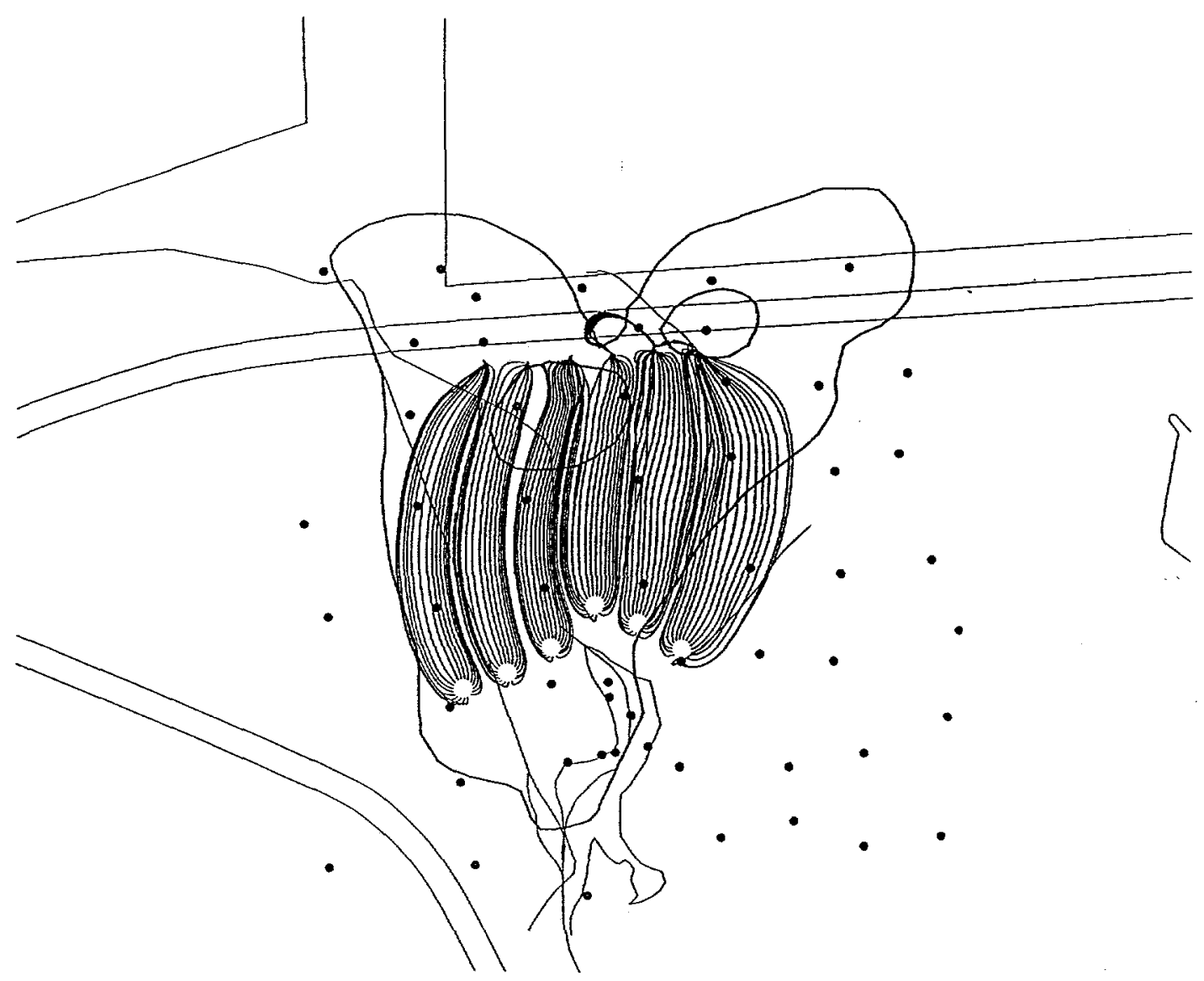

Figure 21. Capture zone within the "Upper Water Table" for well screens above and below the "Tan Clay Confining Zone" with reinjection (200' elevation) 


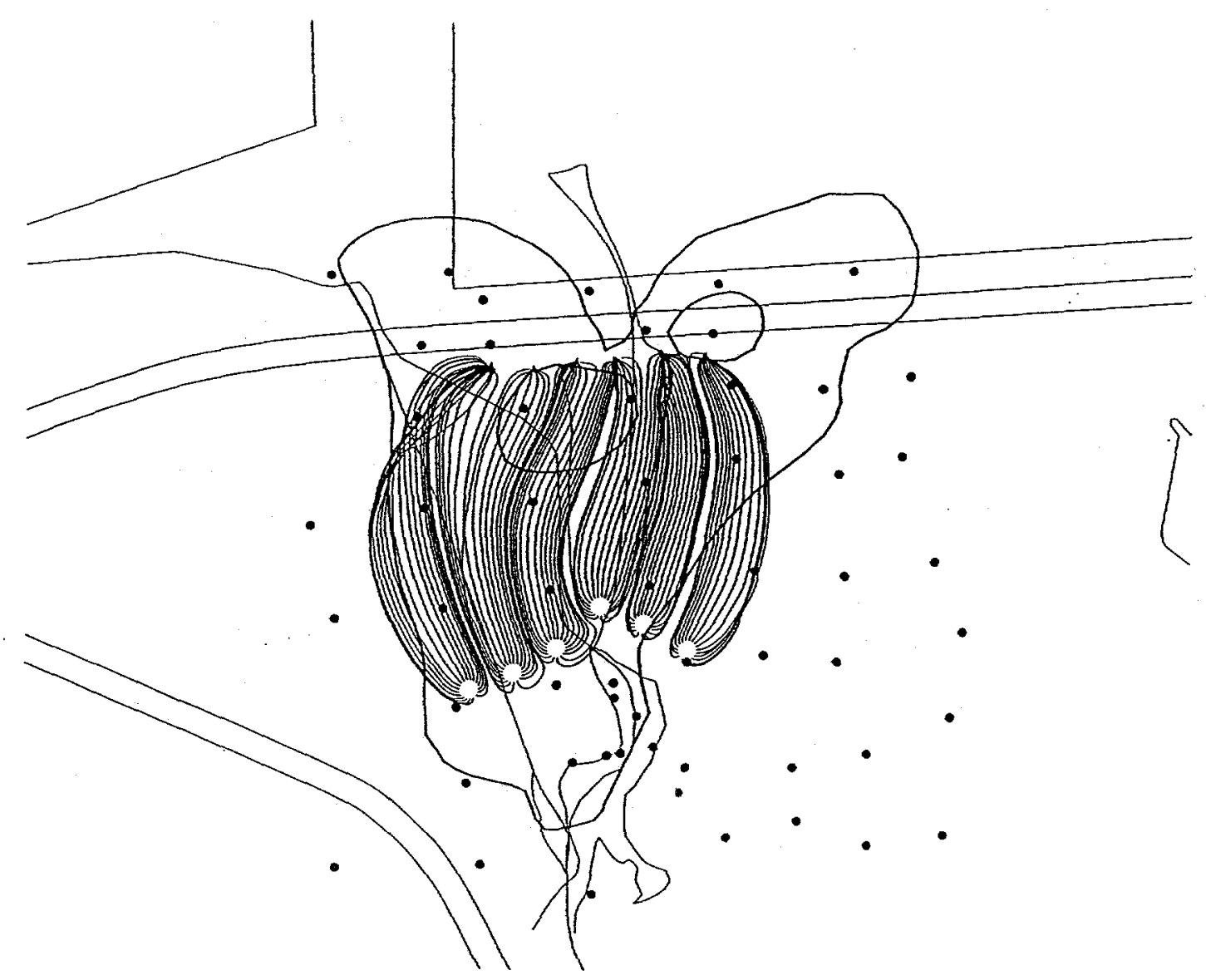

Figure 22. Capture zone within the "Lower Water Table" for well screens above and below the "Tan Clay Confining Zone" with reinjection (180' elevation) 


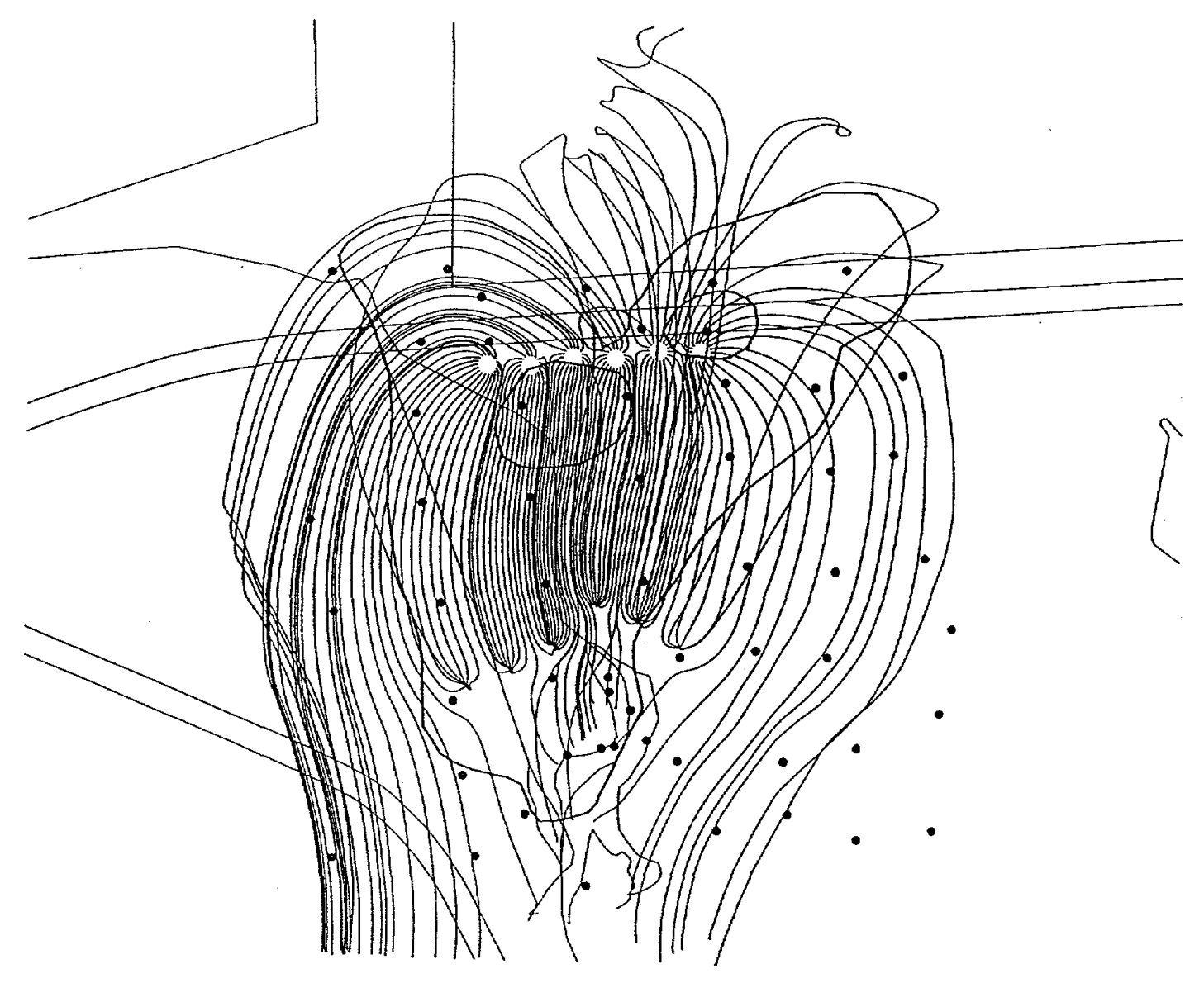

Figure 23. Fate of reinjected tritiated groundwater, $210^{\prime}$ elevation 


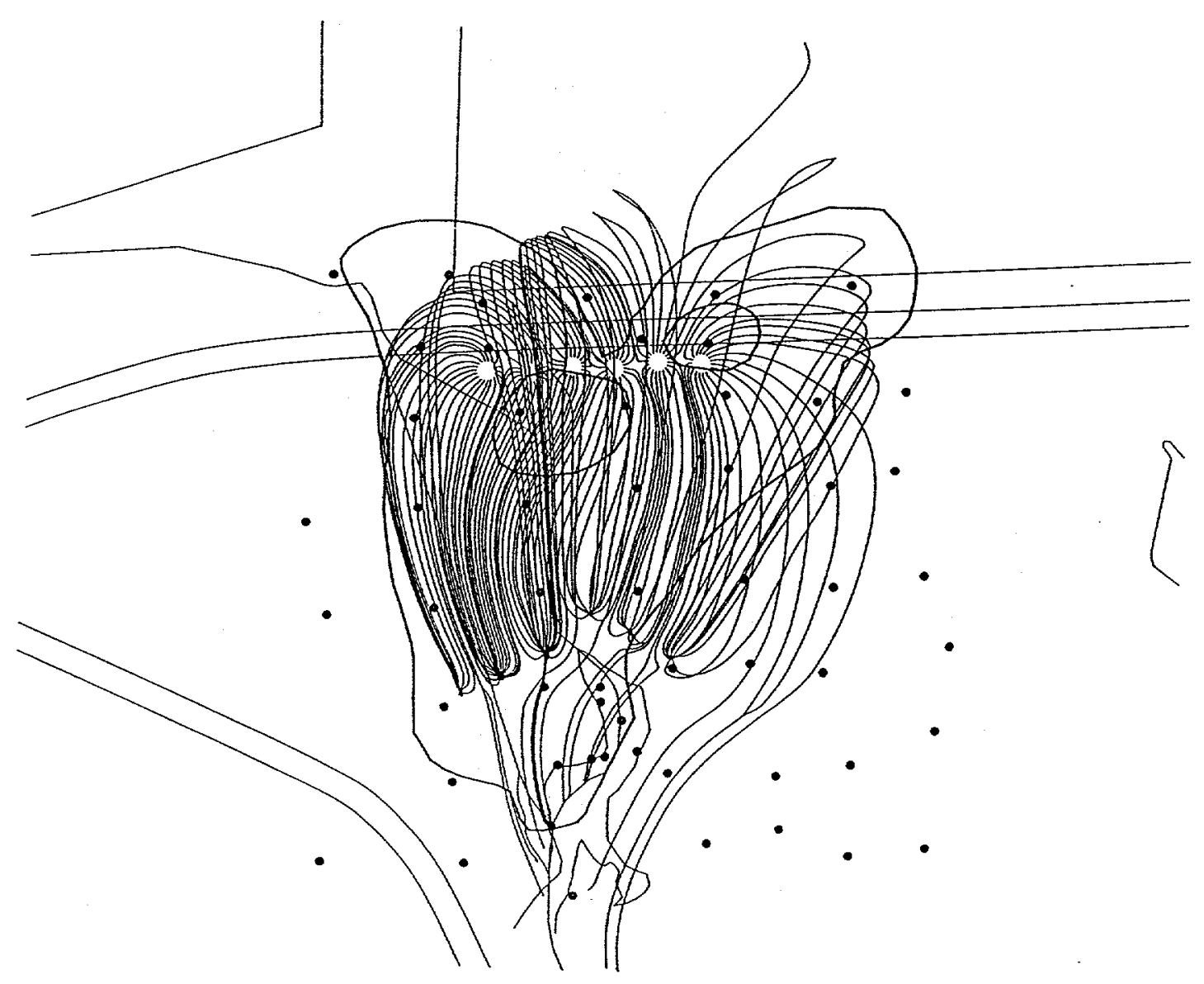

Figure 24. Fate of reinjected tritiated groundwater, 190' elevation 


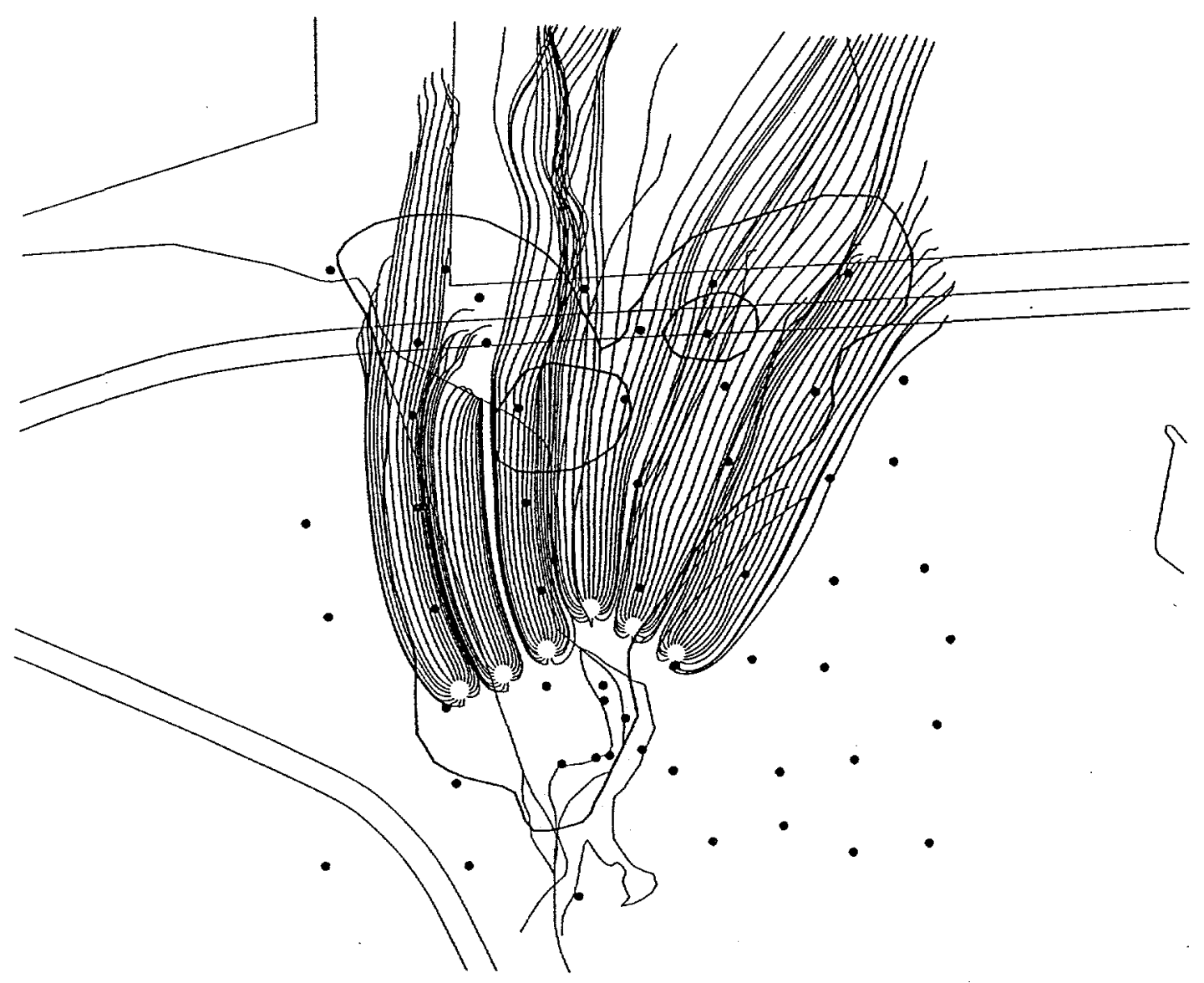

Figure 25. Capture zone within the "Upper Water Table" for well screens above the "Tan Clay Confining Zone" (200' elevation) 


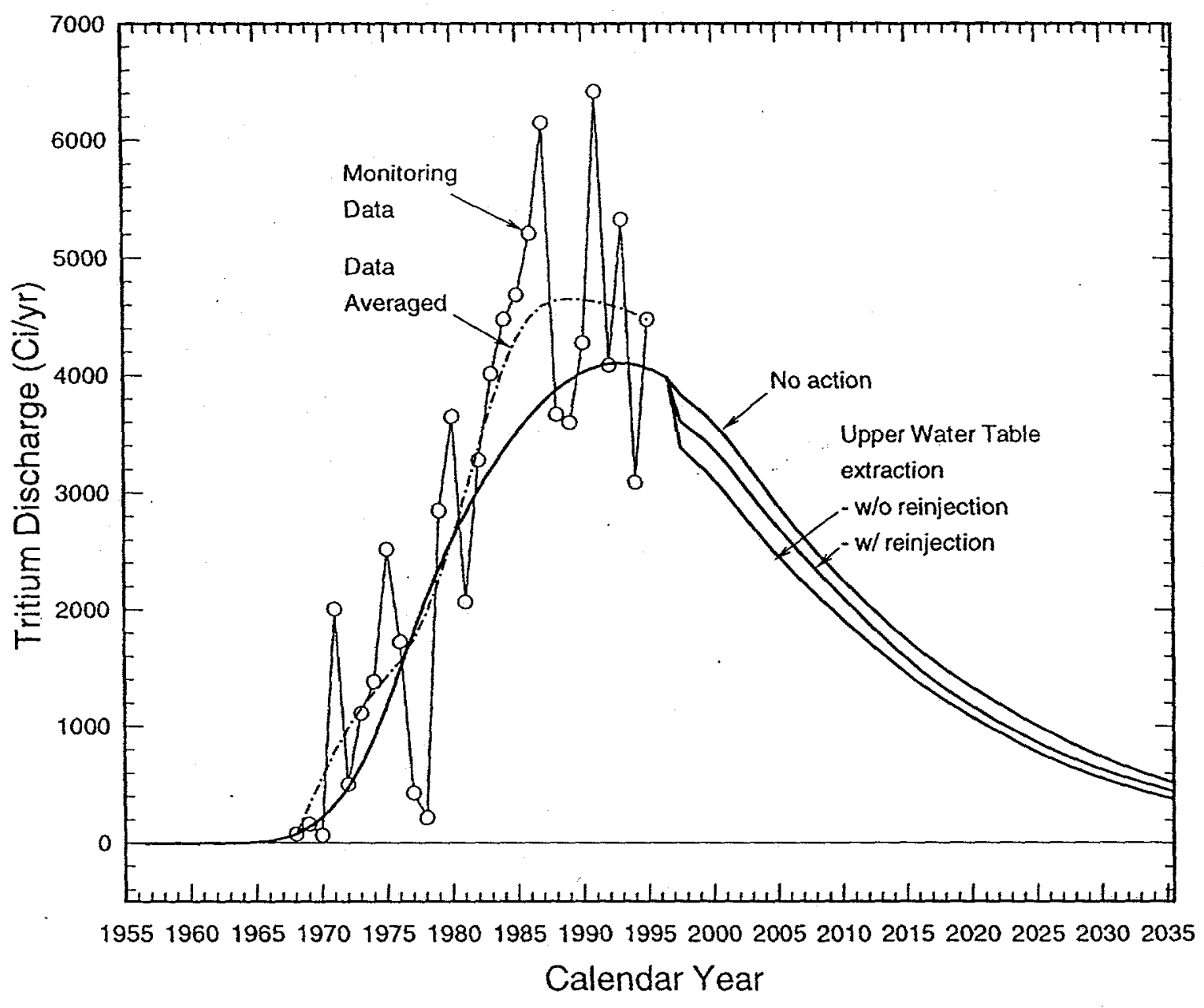

Figure 26. Tritium discharge for "Upper Water Table" capture 


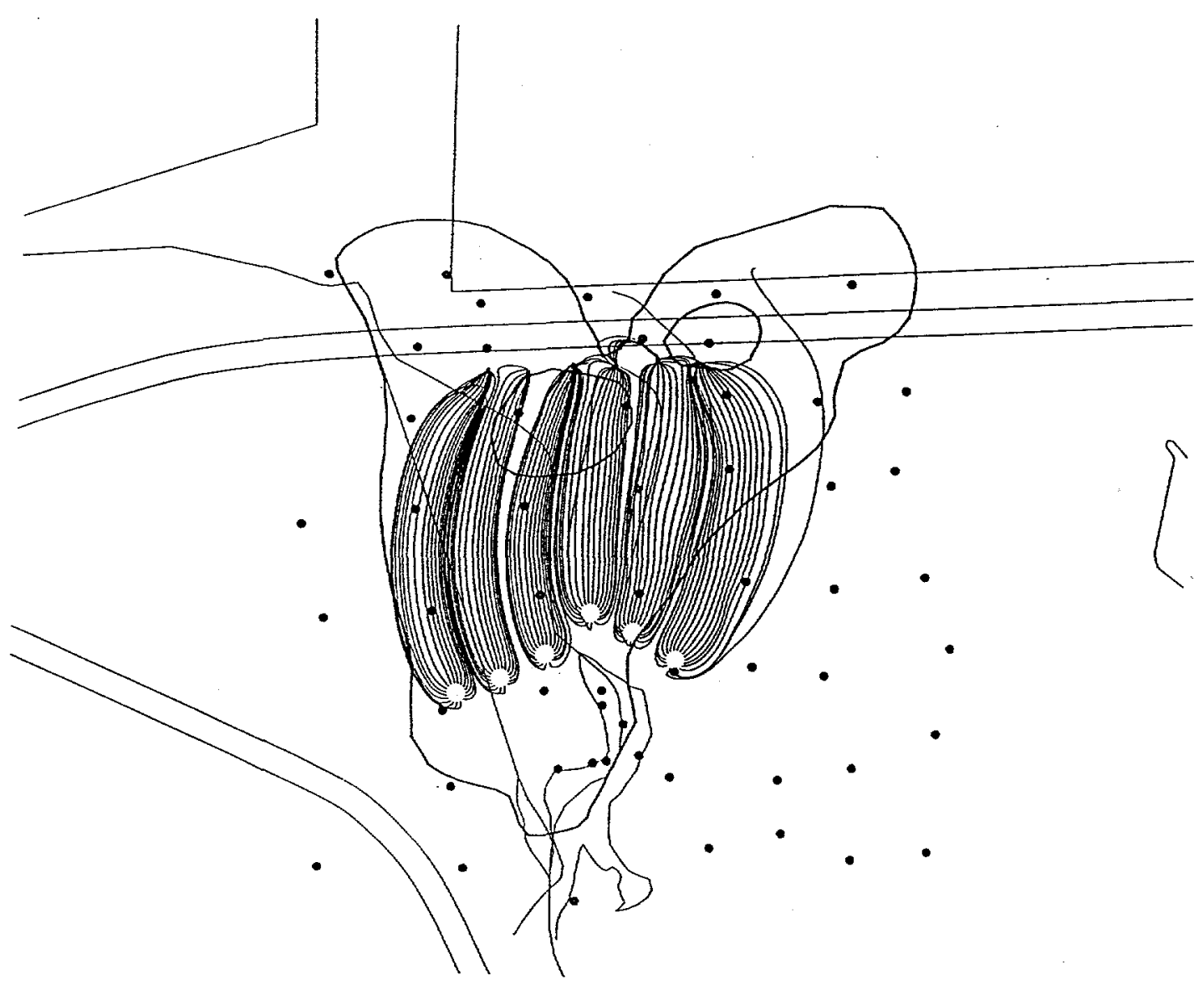

Figure 27. Capture zone within the "Upper Water Table" for well screens above the "Tan Clay Confining Zone" with reinjection (200' elevation) 


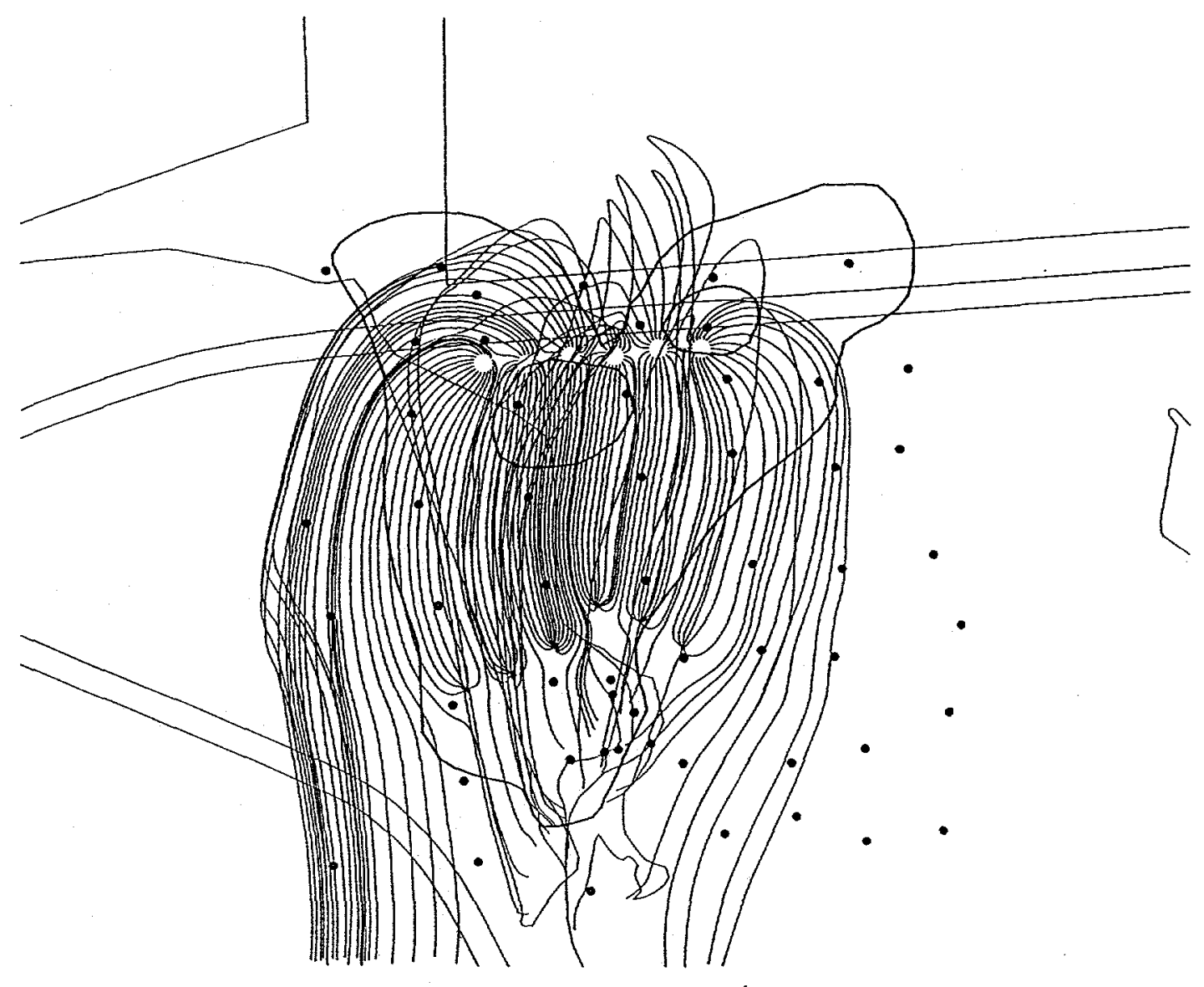

Figure 28. Fate of reinjected tritiated groundwater (210' elevation) 

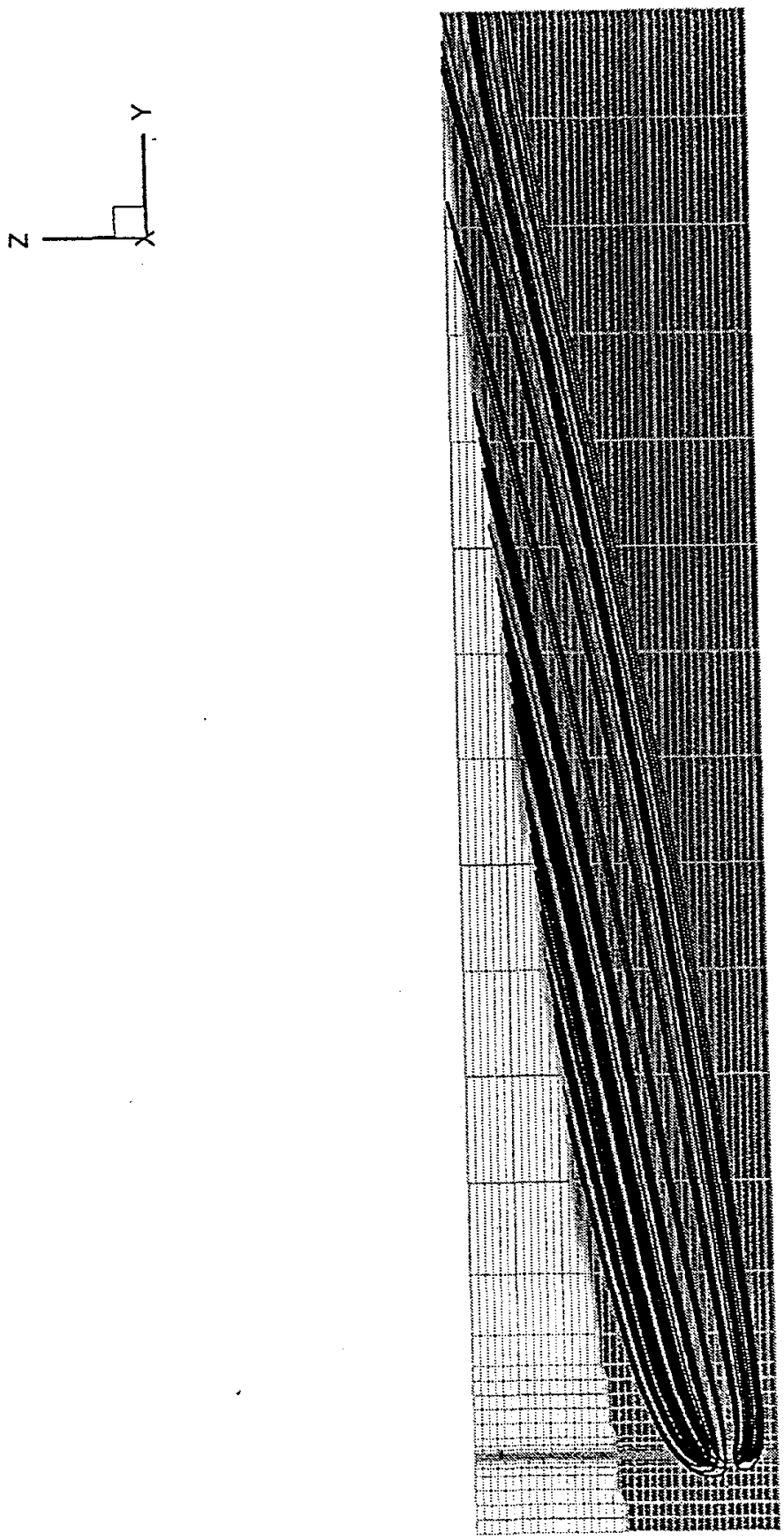

Figure 29. Vertical capture height for depth discrete extraction of "hot layer" scenario 


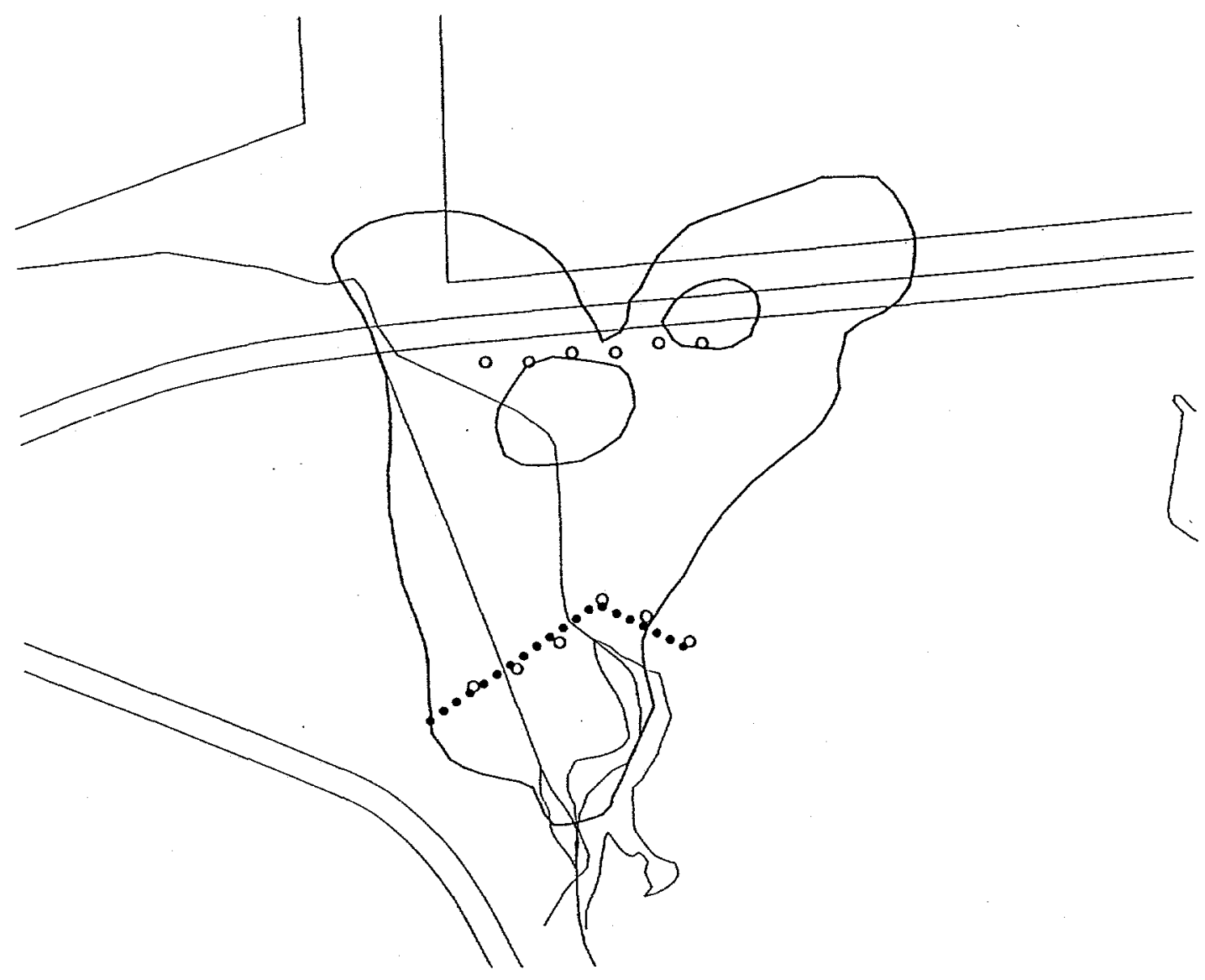

Figure 30. Extraction well placement for "hot layer" extraction scenario 


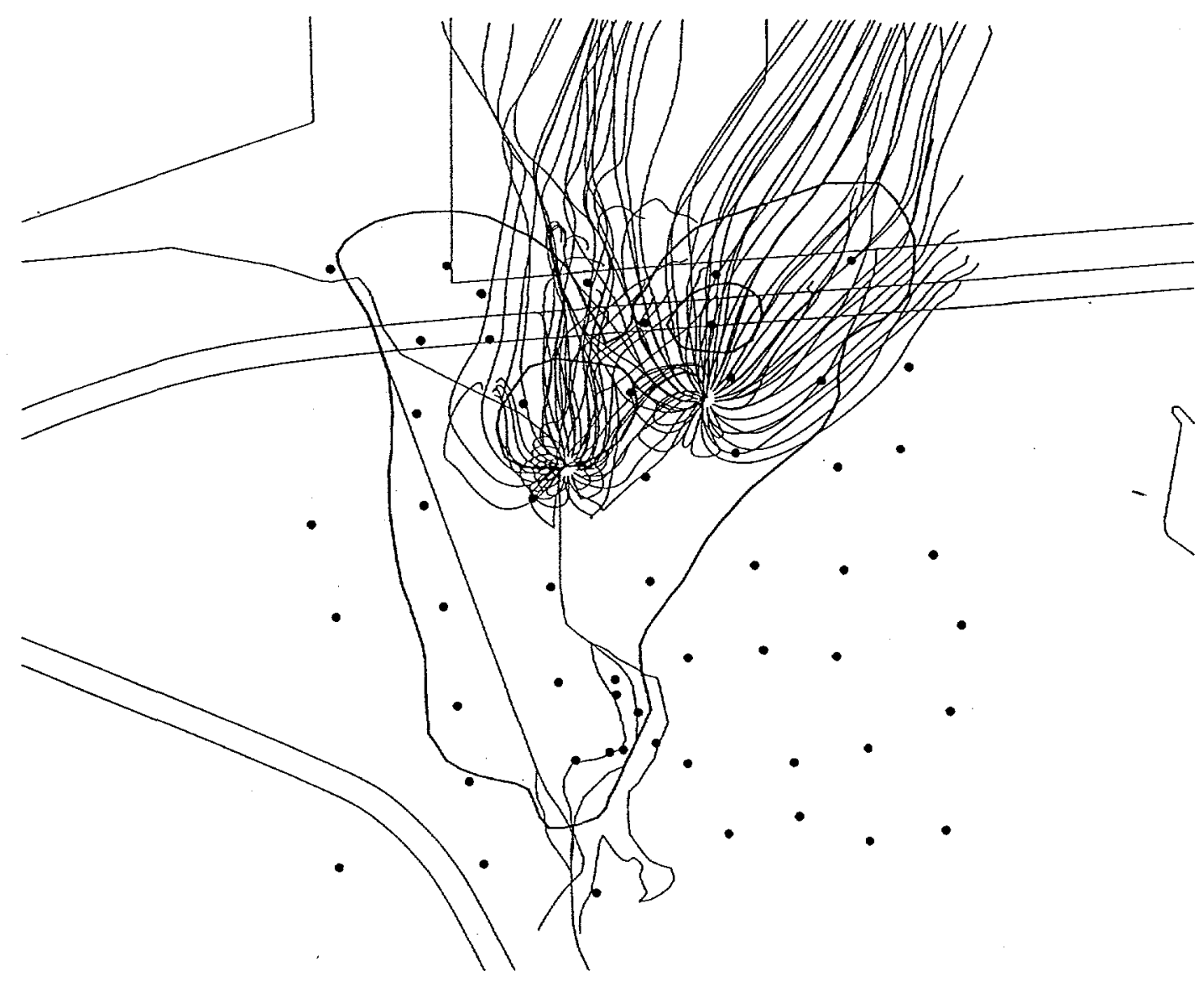

Figure 31. Capture zone for vertical recirculation wells - VOC "hot spots" 


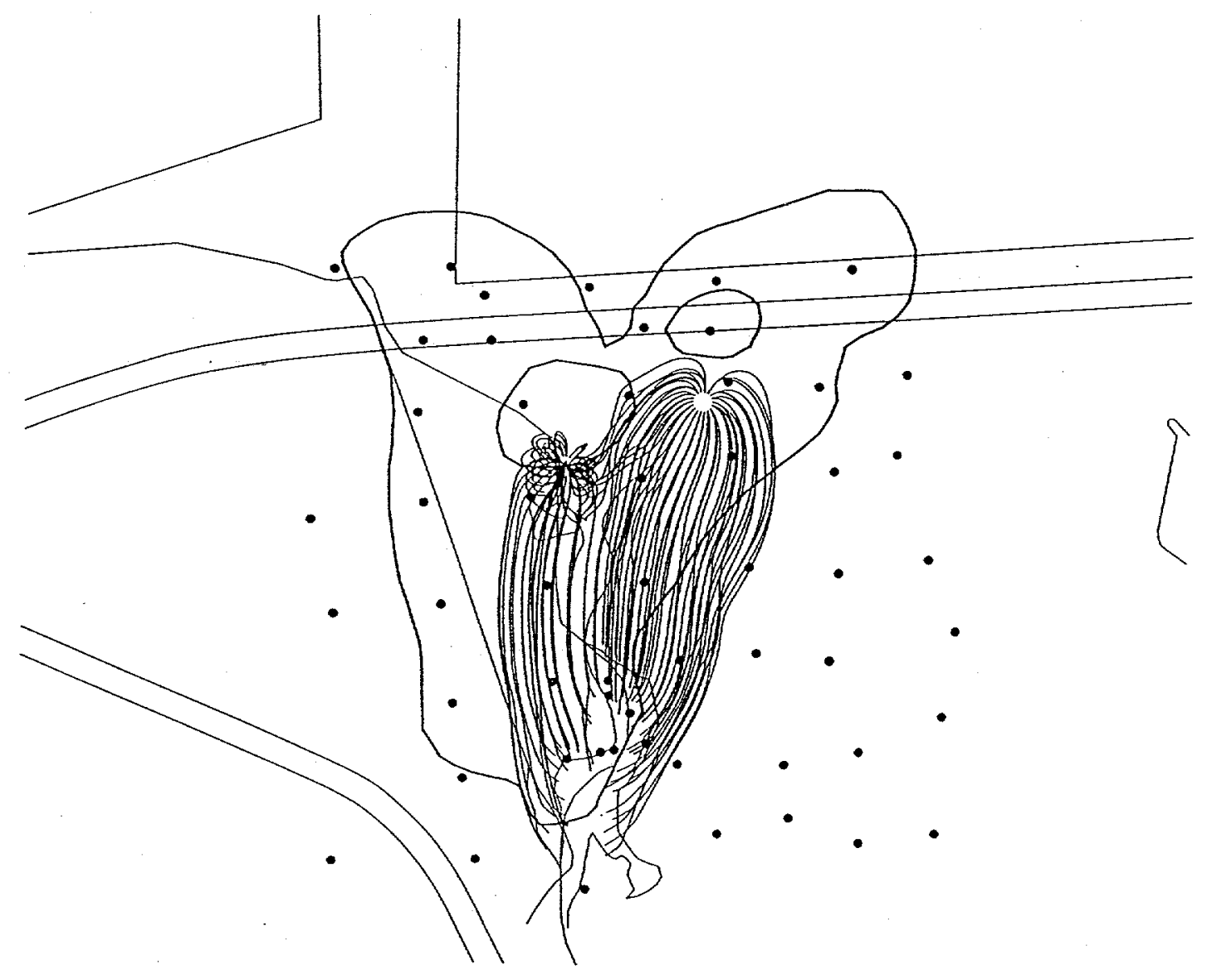

Figure 32. Groundwater flow from vertical recirculation well injection screens - VOC "hot spots" 
THIS PAGE INTENTIONALLY LEFT BLANK 
APPENDLX A

Scoping analysis of the effects of vertical barriers on OBG tritium migration 
THIS PAGE INTENTIONALLY LEFT BLANK 
Vertical barriers to groundwater flow have been proposed as a remedial action at the Old Burial Ground for reducing tritium migration to Fourmile Branch. Vertical barriers can be used to slow and/or divert groundwater flow from the Old Burial Ground to Fourmile Branch. The results of a brief scoping analysis using the FACT model of the Old Burial Ground documented in Flach et al. (1996) are summarized here.

Two hypothetical barrier configurations were considered as shown in Figures 1 and 3 . In both cases, the barriers extend from the ground surface to the Green Clay/Gordon confining unit/Confining Unit IIA-IIB that lies at an elevation of about 120 feet. Ground elevation runs 225 to 250 feet, so the barriers extend $100+$ feet deep. Barriers that stopped at the "tan clay" confining zone were much less effective. Barrier 1 backs up the.groundwater high enough that an above ground barrier (i.e. dam) crossing the old F-area effluent ditch might be required. Barrier 1 is significantly more effective than barrier style 2 (Figures 2 and 4 ), and reduces the tritium release roughly in half compared to no action. Barrier 2 reduces tritium discharge by an amount similar to that achieved by capping the burial ground (see Figure 61 of Flach et al. (1996)). Figure 5 shows the effect of a barrier of style 1 (Figure 1) that extends only to the "tan clay" confining zone.

The results were generated by switching instantaneously in mid-1996 from the current steadystate flow field to the steady-state flow field that results from barrier placement. That is, transient flow effects were ignored. Therefore the results are approximate and should be used qualitatively.

\section{References}

Flach, G. P., L. L. Hamm, M. K. Harris, P. A. Thayer, J. S. Haselow and A. D. Smits, 1996, "Groundwater Flow and Tritium Migration from the SRS Old Burial Ground to Fourmile Branch (U)", WSRC-TR-96-0037. 


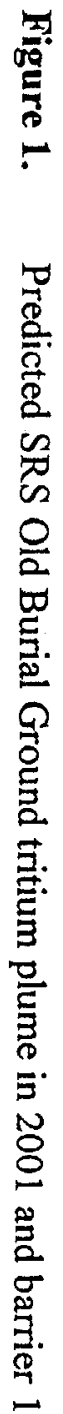

Water Table average concentration $(\mathrm{pCi} / \mathrm{ml})$

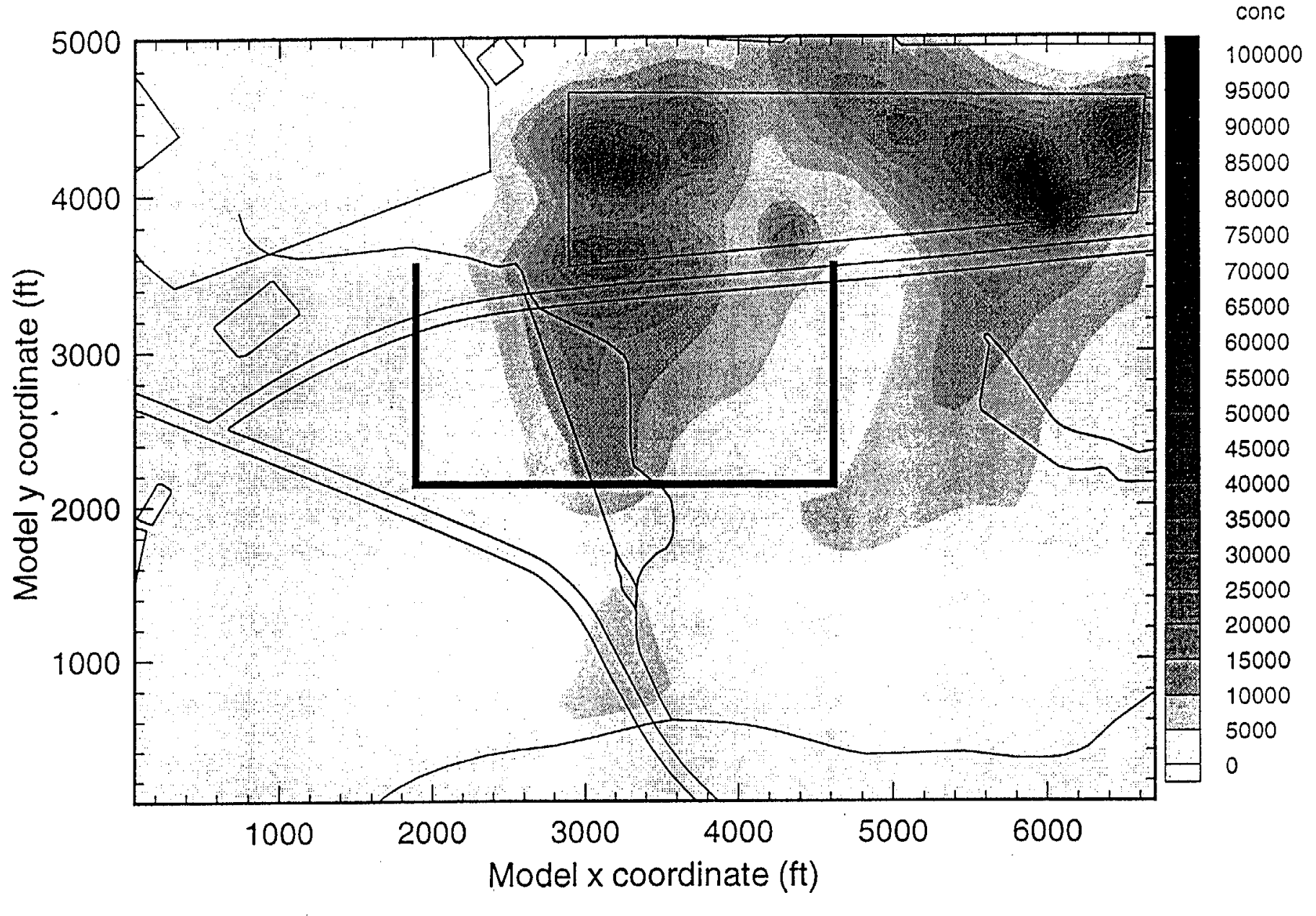




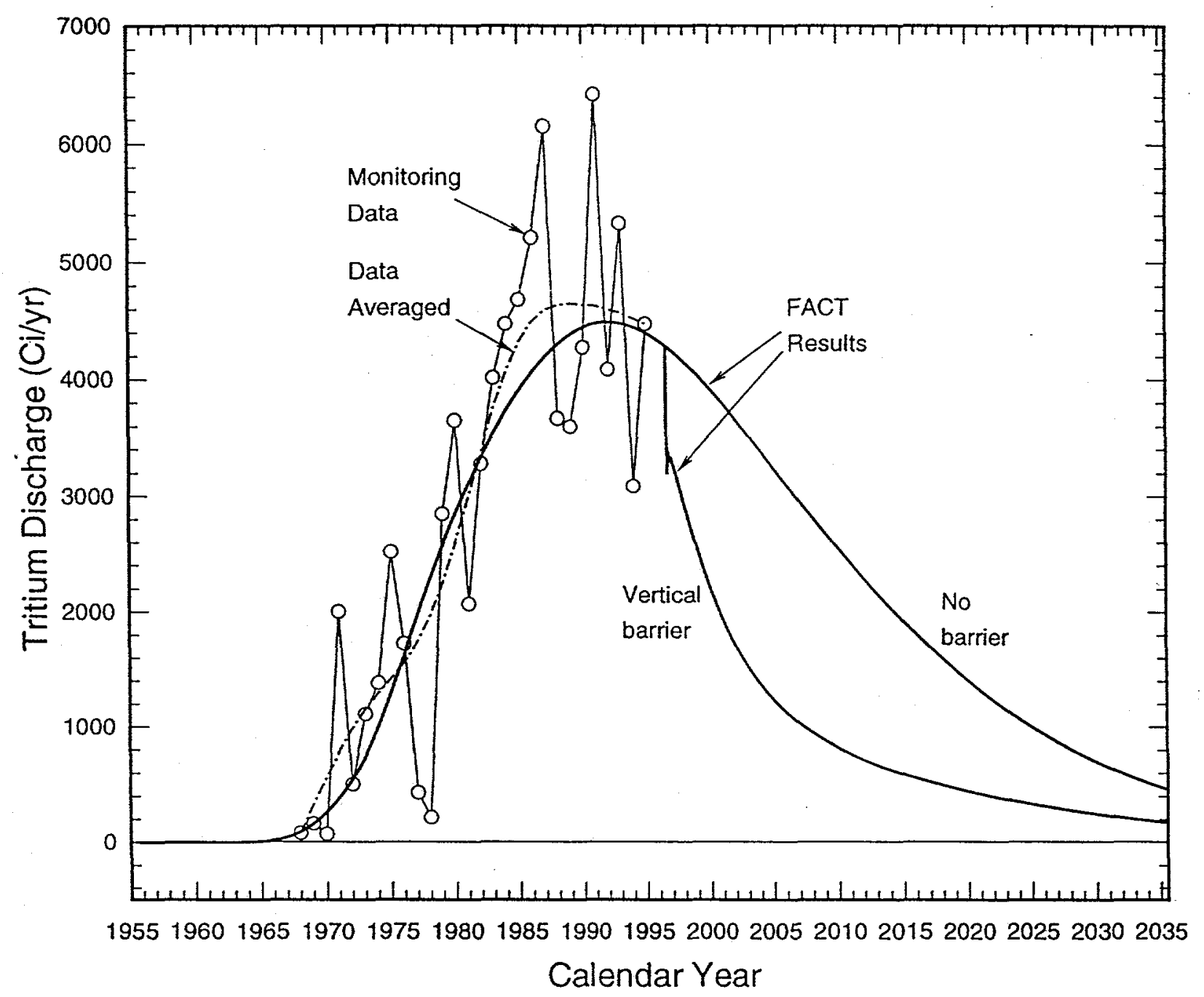

Figure 2. Predicted reduction in tritium discharge to Fourmile Branch from placing barrier 1 


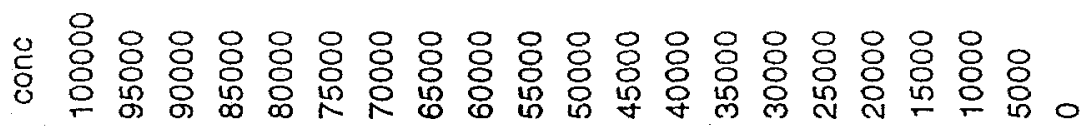

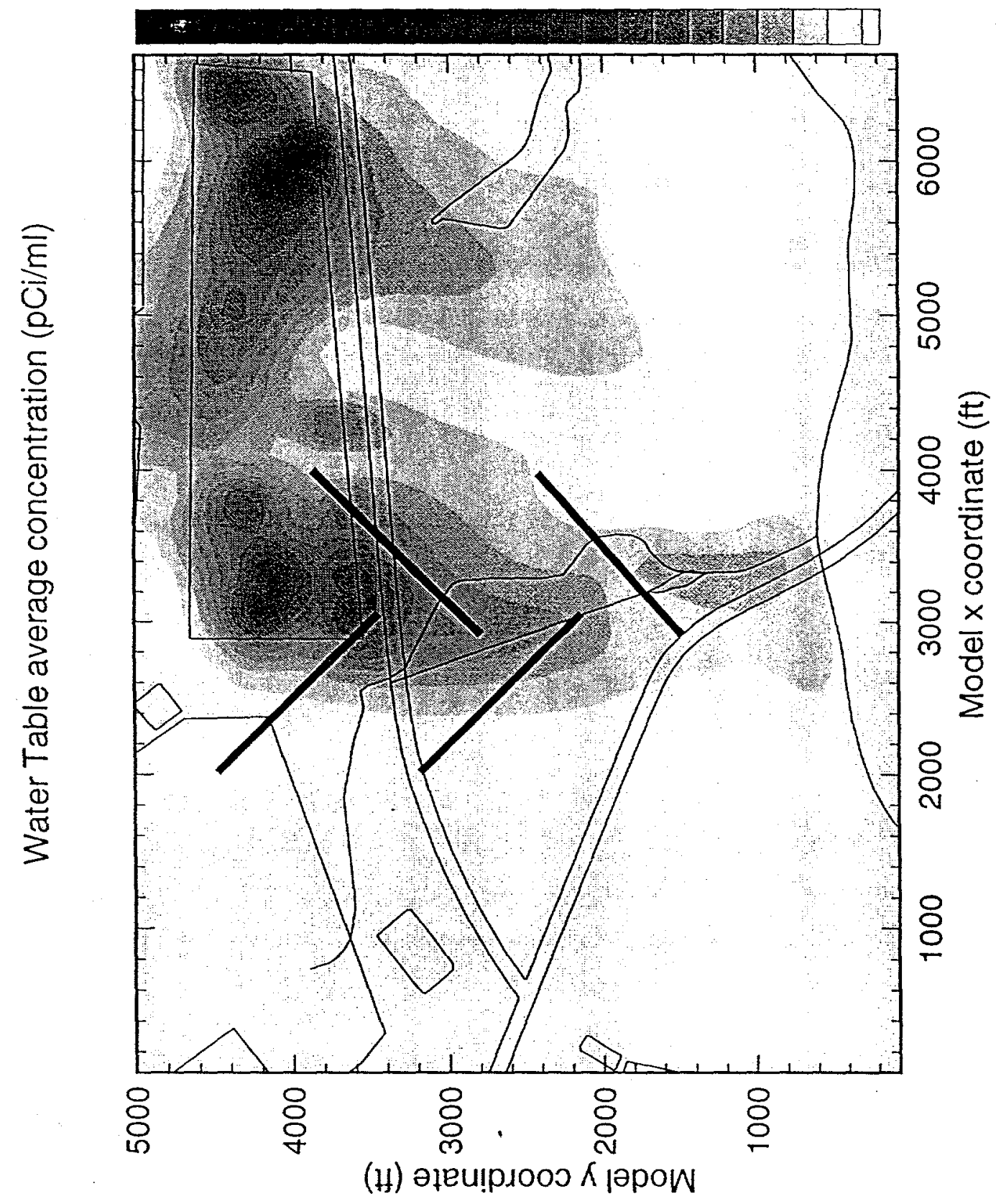

Figure 3. Predicted SRS Old Burial Ground tritium plume in 2001 and barrier 2 


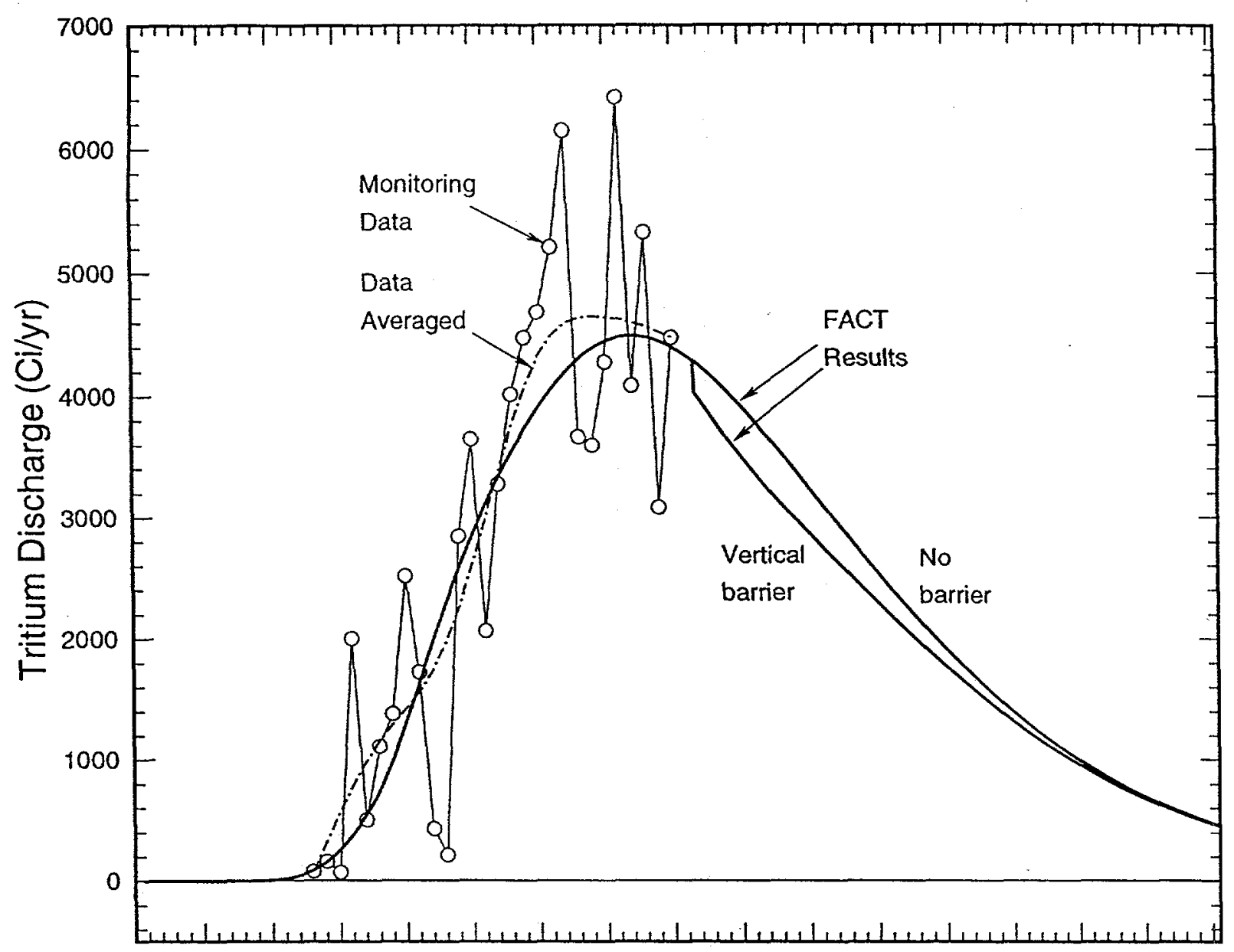

19551960196519701975198019851990199520002005201020152020202520302035

Calendar Year

Figure 4. Predicted reduction in tritium discharge to Fourmile Branch from placing barrier 2 


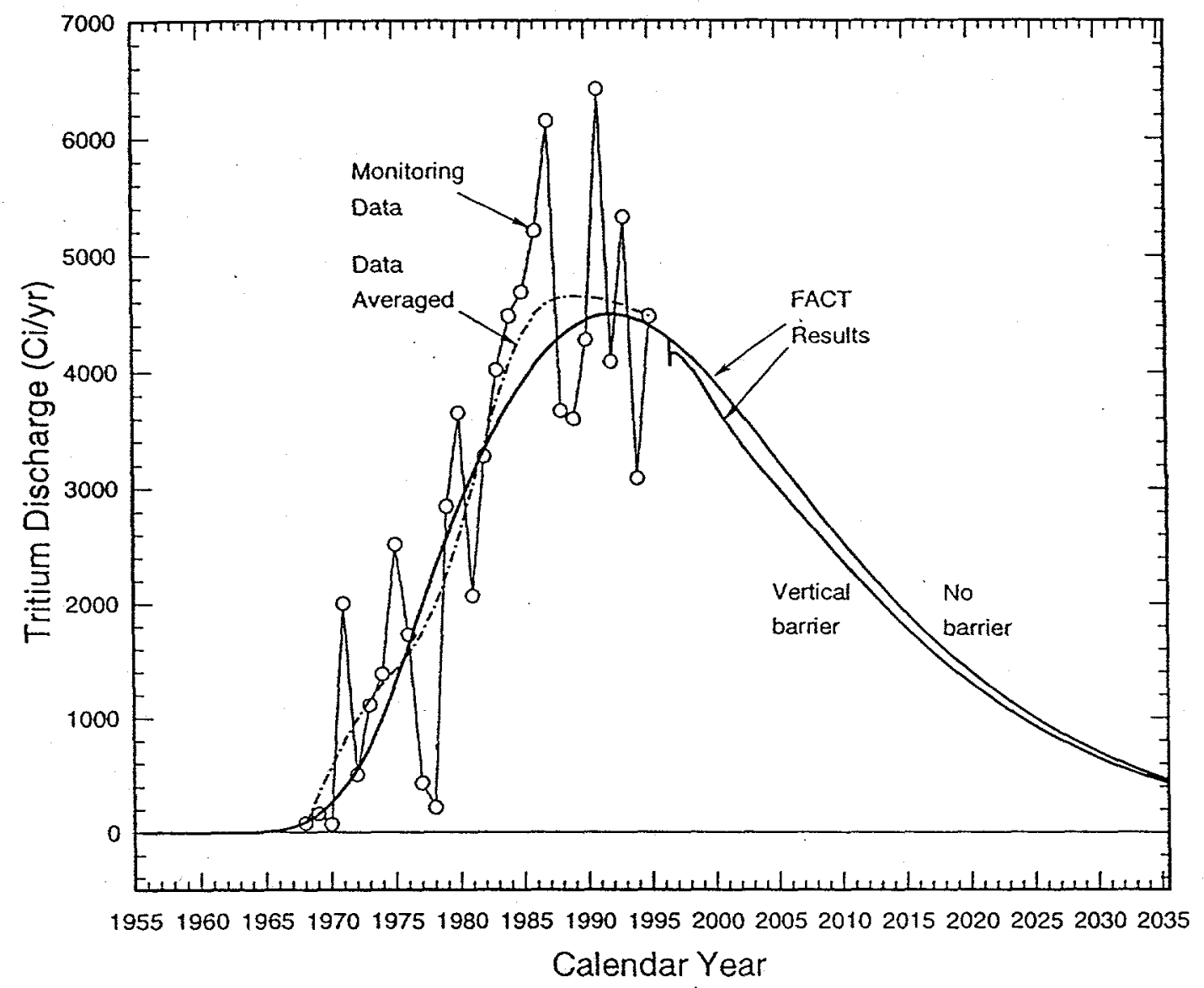

Figure 5. Predicted reduction in tritium discharge to Fourmile Branch from placing a barrier of style 1 (Figure 1) that extends only to the "tan clay" confining zone 


\section{APPENDIX B}

\section{Capture Zone Analysis to Support OBG Corrective Measures Study}


THIS PAGE INTENTIONALLY LEFT BLANK 
A capture zone analysis of two extraction well cases was performed to support the Old Burial Ground Corrective Measures Study. The first scenario is based on treating the Tritium/ACL plume in the "upper" zone of Upper Three Runs aquifer (Water Table, $\mathrm{IIB}_{2}$ aquifer), as depicted in the recent ACL/MZ request (WSRC, 1996, Fig. 2-6). The second is based on treating the TCE/MCL plumes in the Upper Three Runs aquifer (Water Table, $\mathrm{IIB}_{2}$ and Barnwell/McBean, $\mathrm{IIB}_{1}$ aquifers) (WSRC, 1996, Figs. 2-4 and 2-11). The analysis is based on the groundwater flow model of Flach et al. (1996). In order to resolve the detailed flow field around extraction wells, the original mesh was refined as shown in Figure 1. Also, the interim burial ground cap and proposed sedimentation basin were simulated.

Results for the first case are shown in Table 1 and Figure 2. The extraction wells were placed near the seepline with the objective of causing an immediate reduction in contaminant discharge to Fourmile Branch. A minimum of five wells is required to fully capture the up-gradient portions of the plume. Table 2 and Figures 3 and 4 give the results for the second scenario. Pumping wells were placed in both aquifer zones: 5 in the "lower" zone and 6 in the "upper" zone. No reinjection scenarios were analyzed. However, one injection well would likely be needed for each extraction well, based on the F- and $\mathrm{H}$-area seepage basin treatment designs. 
Table 1. Extraction well specifications for treating the Tritium/ACL plume in the "upper" zone of Upper Three Runs aquifer (Water Table, $\mathrm{IBB}_{2}$ aquifer)

\begin{tabular}{|l|l|l|l|l|l|}
\hline Parameter & Well 1 & Well 2 & Well 3 & Well 4 & Well 5 \\
\hline SRS easting, northing (ft) & 53745 & 53933 & 54161 & 54253 & 54325 \\
& 73967 & 73949 & 73983 & 73834 & 73659 \\
\hline Ground elevation (ft) & 246 & 227 & 230 & 233 & 235 \\
\hline Head w/o pumping (ft) & 214.5 & 215 & 217 & 216 & 215 \\
\hline $\begin{array}{l}\text { Head outside well casing } \\
\text { w/pumping (ft) }\end{array}$ & 209.5 & 210 & 211.5 & 210 & 209.5 \\
\hline $\begin{array}{l}\text { Head inside well casing w/pumping } \\
\text { (ft) }\end{array}$ & 205 & 205 & 205 & 206 & 206 \\
\hline Top of screen (ft) & 214 & 213 & 211 & 212.5 & 213 \\
\hline Bottom of screen (ft) & 194.5 & 199 & 197 & 197 & 197 \\
\hline $\begin{array}{l}\text { Top of "tan clay" confining zone } \\
\text { (ft) }\end{array}$ & $\sim 194.5$ & $\sim 199$ & $\sim 197$ & $\sim 197$ & $\sim 197$ \\
\hline Drawdown outside well casing (ft) & 5 & 5 & 5.5 & 6 & 5.5 \\
\hline Drawdown inside well casing (ft) & 9.5 & 10 & 12 & 10 & 9 \\
\hline Well efficiency & $53 \%$ & $50 \%$ & $46 \%$ & $60 \%$ & $61 \%$ \\
\hline Screen length (ft) & 19.5 & 14 & 14 & 15.5 & 16 \\
\hline $\begin{array}{l}\text { Height of water above screen } \\
\text { bottom w/pumping }\end{array}$ & 10.5 & 6 & 8 & 9 & 9 \\
\hline Pumping rate (gpm) & 15.0 & 11.5 & 13.9 & 12.0 & 11.5 \\
\hline
\end{tabular}


Table 2. Extraction well specifications for treating the TCE/MCL plume in Upper Three Runs aquifer (Water Table, $\mathrm{IIB}_{2}$ and Barnwell/McBean, $\mathrm{IIB}_{2}$ aquifers)

\begin{tabular}{|l|l|l|l|l|l|l|}
\hline $\begin{array}{l}\text { WATER TABLE WELLS } \\
\text { Parameter }\end{array}$ & Well 0 & Well 1 & Well 2 & Well 3 & Well 4 & Well 5 \\
\hline SRS easting, northing (ft) & $\begin{array}{l}53576 \\
74011\end{array}$ & $\begin{array}{l}53745 \\
73967\end{array}$ & $\begin{array}{l}53933 \\
73949\end{array}$ & $\begin{array}{l}54161 \\
73983\end{array}$ & $\begin{array}{l}54253 \\
73834\end{array}$ & $\begin{array}{l}54325 \\
73659\end{array}$ \\
\hline Ground elevation (ft) & 251 & 246 & 227 & 230 & 233 & 235 \\
\hline Head w/o pumping (ft) & 214 & 214.5 & 215 & 217 & 216 & 215 \\
\hline $\begin{array}{l}\text { Head outside well casing } \\
\text { w/pumping (ft) }\end{array}$ & 209.5 & 208.5 & 209 & 211 & 209.5 & 208.5 \\
\hline $\begin{array}{l}\text { Head inside well casing } \\
\text { w/pumping (ft) }\end{array}$ & 204 & 204.5 & 204.5 & 206 & 206 & 205 \\
\hline Top of screen (ft) & 209.5 & 214 & 213 & 211 & 212.5 & 213 \\
\hline Bottom of screen (ft) & 195.5 & 194.5 & 199 & 197 & 197 & 197 \\
\hline $\begin{array}{l}\text { Top of "tan clay" confining } \\
\text { zone (ft) }\end{array}$ & $\sim 195.5$ & $\sim 194.5$ & $\sim 199$ & $\sim 197$ & $\sim 197$ & $\sim 197$ \\
\hline $\begin{array}{l}\text { Drawdown outside well } \\
\text { casing (ft) }\end{array}$ & 4.5 & 6 & 6 & 6 & 6.5 & 6.5 \\
\hline $\begin{array}{l}\text { Drawdown inside well casing } \\
\text { (ft) }\end{array}$ & 10 & 10 & 10.5 & 11 & 10 & 10 \\
\hline Well efficiency & $45 \%$ & $60 \%$ & $57 \%$ & $55 \%$ & $65 \%$ & $65 \%$ \\
\hline Screen length (ft) & 14 & 19.5 & 14 & 14 & 15.5 & 16 \\
\hline $\begin{array}{l}\text { Height of water above screen } \\
\text { bottom w/pumping }\end{array}$ & 8.5 & 10 & 5.5 & 9 & 9 & 8 \\
\hline Pumping rate (gpm) & 11.0 & 11.8 & 9.6 & 10.6 & 10.1 & 11.0 \\
\hline
\end{tabular}


Table 2. Extraction well specifications for treating the TCE/MCL plume in Upper Three Runs aquifer (Water Table, $\mathrm{IB}_{2}$ and Barnwell/McBean, $\mathrm{IIB}_{2}$ aquifers) (Cont'd)

\begin{tabular}{|l|l|l|l|l|l|l|}
\hline $\begin{array}{l}\text { BARNWELL/McBEAN } \\
\text { WELLS } \\
\text { Parameter }\end{array}$ & & Well 6 & Well 7 & Well 8 & Well 9 & Well 11 \\
\hline SRS easting, northing (ft) & & 53745 & 53933 & 54161 & 54253 & 54325 \\
\hline Ground elevation (ft) & & 246 & 227 & 230 & 233 & 235 \\
\hline Head w/o pumping (ft) & 212 & 213 & 214 & 213.5 & 213 \\
\hline $\begin{array}{l}\text { Head outside well casing } \\
\text { w/pumping (ft) }\end{array}$ & 208.5 & 209 & 211 & 209.5 & 208.5 \\
\hline $\begin{array}{l}\text { Head inside well casing } \\
\text { w/pumping (ft) }\end{array}$ & 207 & 207 & 208 & 208 & 208 \\
\hline Top of screen (ft) & & 188 & 190 & 187 & 187 & 186 \\
\hline Bottom of screen (ft) & 149 & 150 & 145 & 144 & 143 \\
\hline $\begin{array}{l}\text { Bottom of "tan clay" } \\
\text { confining zone (ft) }\end{array}$ & $185-190$ & $185-190$ & $185-190$ & $185-190$ & $185-190$ \\
\hline $\begin{array}{l}\text { Drawdown outside well } \\
\text { casing (ft) }\end{array}$ & & 3.5 & 4 & 3 & 4 & 4.5 \\
\hline $\begin{array}{l}\text { Drawdown inside well casing } \\
\text { (ft) }\end{array}$ & & 5 & 6 & 6 & 5.5 & 5 \\
\hline Well efficiency & 12.9 & 13.4 & 11.2 & 10.2 & 11.0 \\
\hline Screen length (ft) & $70 \%$ & $67 \%$ & $50 \%$ & $73 \%$ & $90 \%$ \\
\hline $\begin{array}{l}\text { Height of water above screen } \\
\text { bottom w/pumping }\end{array}$ & 39 & 40 & 42 & 43 & 43 \\
\hline Pumping rate (gpm) & - & - & - & - & - \\
\hline
\end{tabular}

\section{References}

Flach, G. P., L. L. Hamm, M. K. Harris, P. A. Thayer, J. S. Haselow, and A. D. Smits, 1996, Groundwater flow and tritium migration from the SRS Old Burial Ground to Fourmile Branch, WSRC-TR-96-0037.

Hamm, L. L., S. E. Aleman, G. P. Flach, W. F. Jones, 1995, FACT: subsurface Flow And Contaminant Transport documentation and user's guide, WSRC-TR-95-0223 (draft).

WSRC, 1996, Alternate concentration limit demonstration/mixing zone request for the southwest plume at the Mixed Waste Management Facility (U), WSRC-RP-96-00136. 


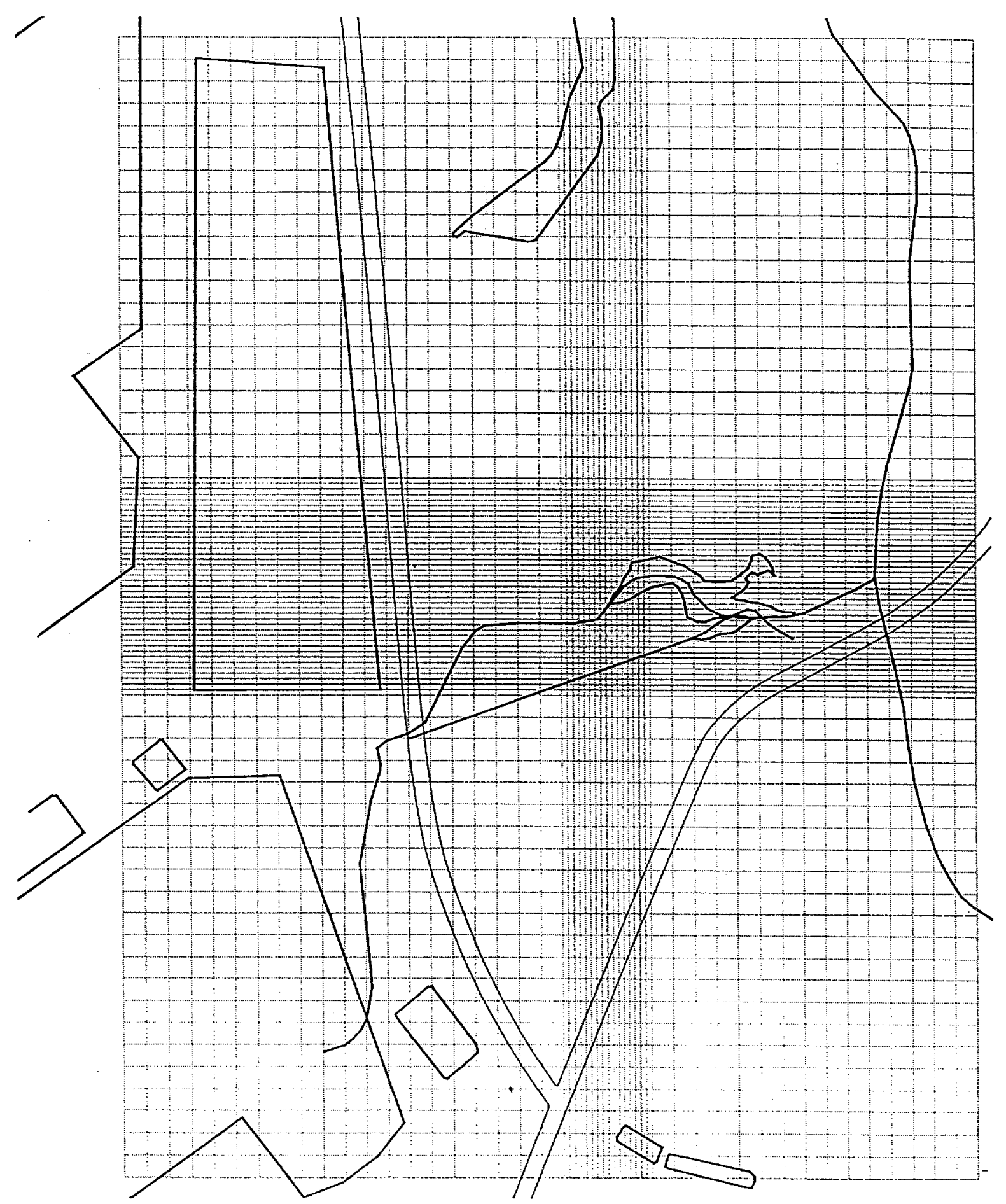

Figure 1. Refined mesh for capture zone analysis 


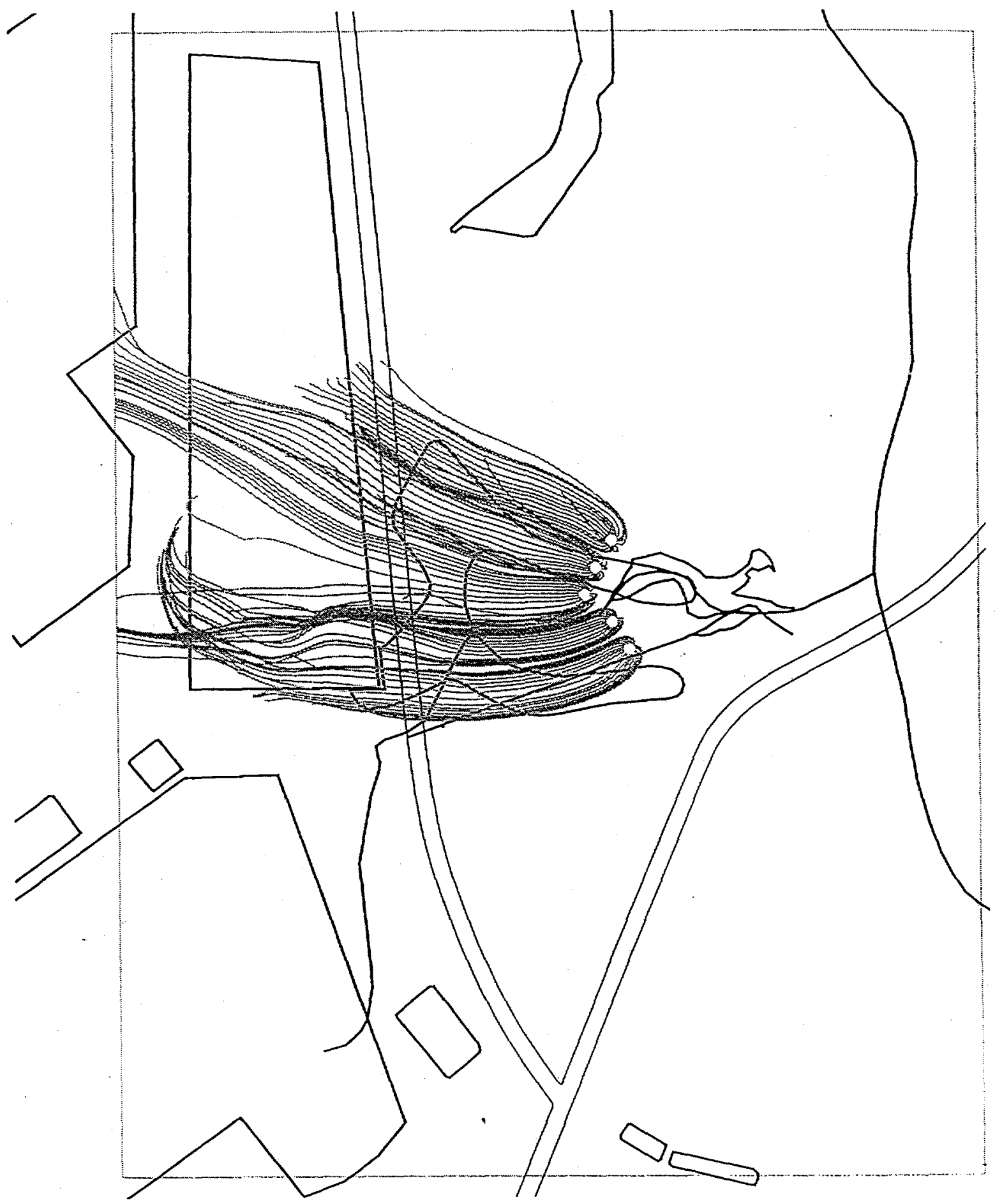

Figure 2. Capture zone within the "upper" zone of Upper Three Runs aquifer (Water Table, $\mathrm{IIB}_{2}$ aquifer) with 5 extraction wells in the "upper" zone 


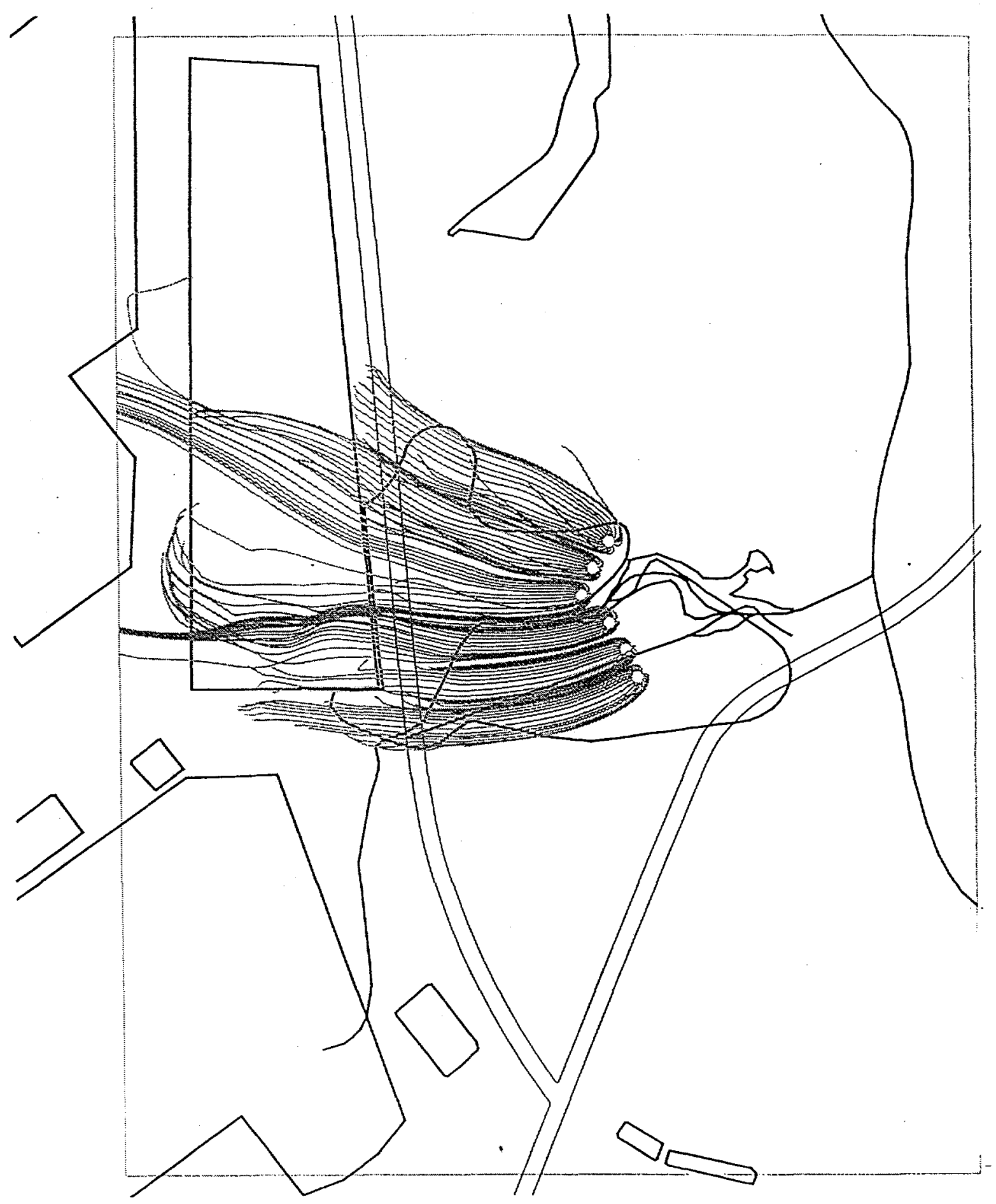

Figure 3. Capture zone within the "upper" zone of Upper Three Runs aquifer (Water Table, $\mathrm{IIB}_{2}$ aquifer) with 6 extraction wells in the "upper" zone and 5 extraction wells in the "lower" zone (Fig. 4) 


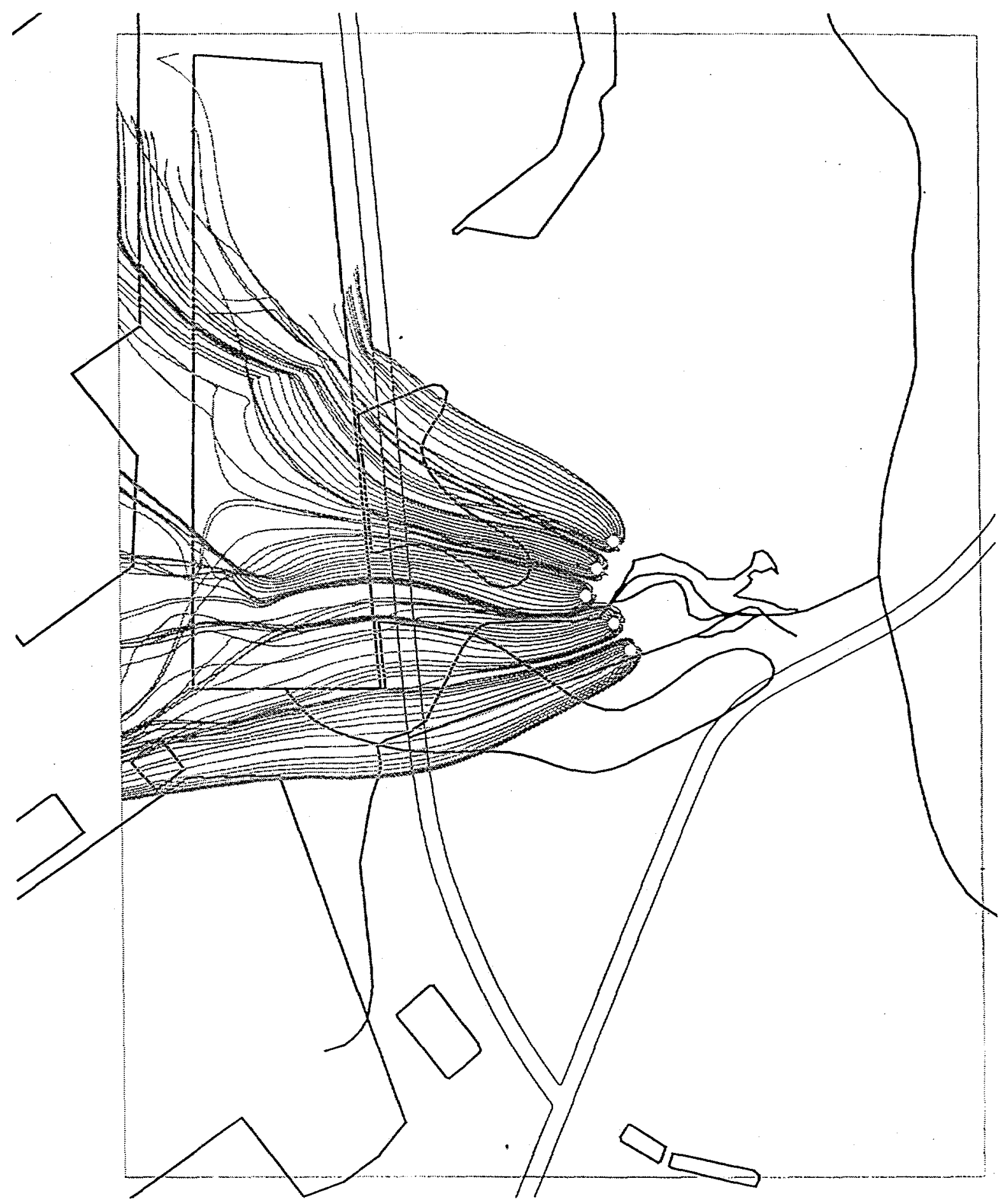

Figure 4. Capture zone within the "lower" zone of Upper Three Runs aquifer (Barnwell/McBean, $\mathrm{IIB}_{1}$ aquifer) with 6 extraction wells in the "upper" zone (Fig. 3) and 5 extraction wells in the "lower" zone 